\title{
Kernos
}

Revue internationale et pluridisciplinaire de religion grecque antique

$22 \mid 2009$

Varia

\section{Divination, Royalty and Insecurity in Classical Sparta}

\section{Anton Powell}

\section{(2) OpenEdition \\ Journals}

\section{Electronic version}

URL: http://journals.openedition.org/kernos/1767

DOI: 10.4000/kernos. 1767

ISSN: 2034-7871

\section{Publisher}

Centre international d'étude de la religion grecque antique

\section{Printed version}

Date of publication: 1 January 2009

Number of pages: $35-82$

ISSN: 0776-3824

Electronic reference

Anton Powell, « Divination, Royalty and Insecurity in Classical Sparta », Kernos [Online], 22 | 2009, Online since 01 October 2012, connection on 19 April 2019. URL : http://journals.openedition.org/ kernos/1767; DOI : 10.4000/kernos.1767 
Kernos 22 (2009), p. 35-82.

\title{
Divination, Royalty and Insecurity in Classical Sparta*
}

\begin{abstract}
Divination forms an unexpectedly high proportion of our total information on Sparta's politics, internal and external. It should be studied diachronically, as well as generically. To abstract it from secular and political context would conceal both causes and effects of religious credulity. We read that Sparta's hereditary dyarchs, the state's chief generals, were appointed, controlled and deposed according to the interpretation of omens and oracles. Grand omens in particular were respected, such as earthquake or a succession of military failures. This was in keeping with the Spartan bias in favour of events that all could perceive. Sparta's kings made famous and apparently extravagant claims to have privileged ancient links with the gods. But by studying the political vulnerability of the kingship, we see these religious pretentions as defensive, the most effective shield for an institution under threat.

Résumé : La divination constitue de façon inattendue une part importante de notre information sur la politique de Sparte, tant intérieure qu'extérieure. On peut l'étudier tant de façon diachronique que dans une perspective générique. L'abstraire de son contexte séculier et politique reviendrait à occulter à la fois les causes et les effets d'une crédulité religieuse. Nous voyons que les deux rois héréditaires de Sparte, les généraux en chef de l'État, étaient désignés, contrôlés et déposés selon l'interprétation des présages et des oracles. Des présages exceptionnels étaient tout particulièrement respectés, comme les tremblements de terre ou une succession de revers militaires. Les Spartiates avaient tendance à mettre en valeur les événements qui étaient visibles de tous. Les rois de Sparte ont avancé de célèbres revendications, apparemment extravagantes, à entretenir d'anciens liens privilégiés avec les dieux. Mais en étudiant la vulnérabilité politique de la royauté, nous constatons que ces prétentions religieuses avaient une portée défensive et formaient une sorte de bouclier très efficace pour une institution menacée.
\end{abstract}

\section{Introduction}

How far, if at all, were Sparta's political decisions influenced by divination? The question leads us into numerous episodes within the classical period; it also challenges traditional scholarly method. Herodotos, Thucydides and Xenophon suggest clearly and often that religious prophecy formed part of Sparta's motiva-

* This paper owes its existence to an invitation from Vinciane Pirenne-Delforge and Carine Van Liefferinge to address the subject in a communication at Bruxelles: sine quibus non. - I am fortunate to have received criticism and advice for the paper from Paul Cartledge, Thomas Figueira, Stephen Hodkinson, Simon Hornblower, Ellen Millender and Karen Radner. I am most grateful for the improvements they have made. 
tion in political matters. Scholars for long tended to react evasively or delicately. ${ }^{1}$ Nowhere, perhaps, is there a published rationale for generally disbelieving what we are told on this subject by these ancient sources who are, for other aspects of Spartan history, properly treated as fundamental. The deservedly influential study of Spartan religion by Robert Parker (1989) collects, in its dense treasury of information, prima facie evidence that divination had the power to reverse the public undertakings of Spartan authorities: on several occasions Spartan military expeditions already under way were postponed or abandoned in the face of negative omens. ${ }^{2}$ Here, it may seem, is behaviour to compare with that of the Athenian-led troops in Sicily in 413 who, on Thucydides' showing, because of divination about a lunar eclipse dropped their clamorous insistence on a prompt departure from Syracuse and instead urged their generals to remain. ${ }^{3}$

Yet, in the twenty years since the appearance of Parker's work, scholarly opinion both on Spartan history and on Greek divination has changed considerably. It may be allowable now for an admirer of that work to challenge one aspect of it: namely, Parker's response to the question how influential divination was among Spartans. That response may seem itself to have a somewhat Delphic quality. On the one hand, Parker implies disapproval of the way that 'Almost every incident of a campaign abandoned or an attack postponed because of unpromising omens has received a rationalising explanation from one scholar or another' $(1989,157 f$.). He writes that Spartans 'heeded divine signs and obeyed the rules' $(1989,161)$; 'the power of prophecy' (ibid.) among Spartans reflected a distinctive local attitude. On the other hand, he states that 'Divination was doubtless under control in Sparta, as it normally is wherever it is practised' (1989, 160). He notes with ironic disapproval that 'The charm of divination for the consultant is that he need never feel that he is acting at random' (ibid.). He himself rationalises about the apparent power of omens to affect military expeditions: 'If, therefore, a plan or expedition was abandoned because of the lesser obstacle of discouraging sacrifices, the king must either have been unusually timorous, or have felt genuine doubt whether the proposed action was wise' (1989, 159-60; emphasis added). He likens divination among Spartans to the economic forecasting of modern times: 'Politicians believe profoundly in

\footnotetext{
${ }^{1}$ For an example of delicate evasiveness, Fontenrose, in a general conclusion about Delphic history: 'What effect or influence did Delphi have upon the Greek states? If we look through genuine responses, we must say that it had no direct and active influence upon them...' (1978, p. 239). One notices the triple qualification ('genuine', 'direct', 'active'): how much is being excluded thereby? Contrast PRITCHETT (1979), p. 298, 300: 'Certainly the oracle at Delphi had immense influence'. On the (typically unavowed) reasons for modern disbelief in influential ancient divination, POWELl (2001), p. 423-7, FlOWER (2008), p. 245, JOHNSTON (2008), p. 23.

2 1989, 156-7. Other scholars who have taken seriously evidence of Spartan regard for divination include Grote, Popp (1957), PritchetT (1979) esp. chs. 1, 3, 9, HodkINSON (1983), p. 273-6, Holladay and GOODMAN (1986), p. 155f., CARTLEDGe (1987), JACQUEMIN (2000), p. 102-104.

3 Thuc., VII, 50, 4 with VII, 47, 1f., 48, 4; POwELL (1979a).
} 
economic predictions; politicians are sometimes swayed by economic advice; politicians find ways of carrying through certain favoured policies whatever economic advisers may say.' (160) Here, as 'profound belief gives way to 'sometimes swayed', we are left in some doubt as to the practical force of economic, and thus divinatory, forecasts to affect decisions. Parker writes of modern historians as 'embarrassed' by ancient accounts of military divination $(1989,157)$. In seeking to negotiate the distance between those modern scholars incredulous of the sources and those who take them seriously or between, as Parker puts it, 'scepticism of the sceptics... shown up as dogmatic' and 'something simplistic about the faith of the believers' (1989, 158), a modern writer may well have recourse to irony and obscurity for reasons that an ancient diviner would have recognised.

\section{For a diachronic approach}

As members of a rationalist tradition of history, we may have learned to read our sources counter-religiously. Thus when we meet, in Thucydides, lists of those who, on Athens' behalf, swore (not 'signed') treaties with Sparta, our eye may be tempted to move to the names of the generals and lay politicians, Lakhes and Nikias, Lamakhos, Demosthenes and the rest, while cognitively resisting the fact that at the head of the list, on two occasions, comes the seer Lampon ( V, 19, 2; $24,1)$. The present paper may even surprise, not only by the volume of surviving ancient references to religion in Sparta's political and military affairs, but especially by the proportion which they form of our total information on those subjects. And, if we do become aware of the prominence of religion in our sources, even in Thucydides who - when writing of Athens - has rightly been judged parsimonious in his references to political divination, ${ }^{4}$ we may be tempted - in reaction - to re-emphasise that prophecy by playing down its apparently secular context, the context which caused religion to be neglected in the first place. But by abstracting religion in this way, we may reduce our ability to judge its role, its comparative importance, in the discourse of the polis. Parker has successfully studied Spartan religion in anthropological style: that is, organising material primarily by categories of behaviour which transcend chronology. However, a risk inherent in this approach is that it may encourage what has been called 'the anthropological present tense', and tend to hide developments within the culture studied. Such a risk would be particularly serious in the case of Sparta, a society which worked successfully to impose a false view of its own 'unchanging' character: an extreme case of such is the claim which Thucydides accepted (I, $18,1)$, that Sparta had enjoyed the same constitution for 'slightly more than 400 years'. Modern scholarship is increasingly convinced that Sparta did change

${ }^{4}$ HORnBlower (1992), and below, n. 44. 
profoundly, culturally as demographically, over the four centuries $\left(6^{\text {th }}-3^{\text {rd }}\right.$ BC) which provide most of our evidence for its religious belief and practice. ${ }^{5}$ Evidence for change in Spartan attitudes to particular authorities is well known. Most relevant here is the official eviction (or indeed killing) of several kings (or, in the case of Pausanias, of a regent), since the kings were believed at Sparta to be of divine descent ${ }^{6}$ and to have Delphic sanction for their authority. ${ }^{7}$ They also had a pre-eminent position (as Parker well shows) in the conduct of religion ${ }^{8}$ and in particular in the procuring and controlling of oracular responses from the Delphic oracle. ${ }^{9}$ Now, because Spartan attitudes could change drastically towards the royal bearers and mediators of this form of religious authority, we should also enquire whether the credit of particular sources of divination, shrines and seers, might vary according to how events, and especially very recent events, seemed to confirm or refute their prophecies. And in trying to answer that question a chronological approach seems essential, if only as a complement to the anthropological method. A result of this diachronic method will be to cast unexpected new light on the stability - or otherwise - of the very institution of Spartan dyarchy.

\section{Our evidence}

The student of Spartan religion depends for much information on two very different sets of literary material. Pausanias, the antiquarian and travel-writer of the second century AD, gives invaluable detail from autopsy of physical evidence concerning earlier Spartan religious cult. This set of information, well deployed by Parker, is inevitably deficient in matters of historical context; Pausanias knows or tells little of the circumstances in which were created the various Lakonian buildings and statues to which he attests. Then there is our information on Spartan religious belief and practice contained in accounts from the classical period. Here are very different problems and possibilities. Much of what we hear about Sparta comes from narratives concerning an individual and offering a rare intensity of detail amid general darkness. ${ }^{10}$ The individual tends to be a Spartan leader (presented as dissident or, more rarely, hero), whose death provides a

\footnotetext{
5 This is a prominent theme in the two most important monographs on Sparta in recent years, CARTLEDGe (1987) and Hodkinson (2000). In Powell (1998) I examined evidence from vase-painting that the austere Spartan constitution did not antedate the second half of the sixth

6 Thuc., V, 16, 2, cf. Hdt., VI, 58f. with PARKer (1989), p. 169 n. 52.

${ }^{7}$ See below, p. 76.

8 The kings as priests of Zeus: Hdt., VI, 56; as having general charge of religion: Ar., Pol., 1285a. Cf. PARKER (1989), p. $154 f$.

${ }^{9}$ Hdt., VI, 57.

10 Millender (2002), p. 2: 'Most of the disparate information on Sparta included in the Histories clusters around the figures of the Spartan kings and renders Herodotus' portrait of Sparta essentially a series of royal biographical sketches.'
} century. 
focus for moralising. Our picture of Spartan politics in the early fifth century is structured by stories of two egregious rulers and their bad deaths: king Kleomenes $\mathrm{I}$ and regent Pausanias. The narrative leading to the good death of king Leonidas, at Thermopylai, contains much of the information we have about the Persian invasion. The narrative of the downfall, persecution and death of the Athenian Themistokles is connected by Thucydides with the story of Pausanias' decline and fall: against both men is cast the accusation of collusion with Persia. Themistokles, as Thucydides' account makes clear, had moved from being intimately admired by the Spartans to being a principal enemy of their state. Although neither king Pleistoanax (first exiled then restored), nor king Agis II (threatened with an enormous fine and with the demolition of his house, clear signs of a projected exile ${ }^{11}$ ) came to a bad end, defamatory suspicions about both men provide a considerable part of our information on Spartan constitutional history later in the fifth century. For the start of the fourth century, the conspiracy of Kinadon as narrated by Xenophon provides a further cluster of revealing detail. And shortly after the death of Lysandros (395), information came to light or was invented - of an elaborate plot which he had constructed to subvert the Spartan kingship in the interests of his own career; a detailed narrative survives in Diodorus and Plutarch, drawn from Ephorus: both plots, as recorded, involved divination. The tendency of Spartan history, as we and our literary sources construct it, to be shaped by narrative of problematic Spartan leaders is no less clear after the classical period. Following many decades for which we hear little, for the later third century we have from Plutarch (drawing, most probably, on Phylarkhos) lavishly-detailed Lives of the careers of two kings, Agis IV and Kleomenes III, both of whom undertook political and social revolution in Lakonia and came to picturesque ends. The first was (controversially) hanged at Sparta, the other is shown as nobly committing suicide after an attempt against overwhelming odds to subvert Ptolemaic rule in Alexandria. The death of the first, that is, recalls that of the regent Pausanias; in contrast, Kleomenes in Egypt recalls Leonidas at Thermopylai. ${ }^{12}$ After these dramatized episodes, and a last flourish of colourful detail concerning the ruler Nabis, Spartan history, for us, abruptly reverts for the most part to darkness.

These narrative episodes with their binary morality, their interest in death, their frequent insistence on the qualities of individuals and on the Spartan constitution, all seem likely to have derived their fundamental character from stories told at Sparta. Spartan pre-occupation with preserving (or, in the case of the two third-century kings, with restoring) the supposedly-traditional constitution seems to have generated a narrative pattern: those leaders whose preeminence or misbehaviour threatened the familiar order of the Similars, the

11 Thuc., V, 63, 2. King Leotykhidas, exiled from Sparta half an century earlier, had also been subject to the demolition of his residence: Hdt., VI, 72.

12 Powell (1999). 
bomoioi, were in retrospect enduringly vilified, while those whose qualities promoted that regime were glowingly eulogized, in both cases with special attention to the circumstances of their deaths. Much of 'Spartan history', we must suspect, originated not as an abstract exercise in truth-telling but as a constitutional instrument.

Even the most recent and pertinent history, the true outlines of which would predictably emerge before long, could be falsified for the sake of Sparta's wellbeing. Xenophon shows that Sparta's resounding naval defeats at Arginousai (406) and Knidos (394) were initially and with conscious mendacity presented by Spartan commanders elsewhere as victories, through concern to protect the morale of their troops. ${ }^{13}$ The utterances of mendacious partisans are, however, very far from being historically valueless. We mistrust the points which Spartans allege with the greatest emphasis and colour, as for example that Kleomenes I was mad, Leonidas self-sacrificing from patriotism, Pausanias pro-Persian and Lysandros subversive. Here perhaps is the work of Spartans seeking to persuade other Spartans. What is likely to reflect the more general beliefs of Spartan society are the points which are implicit, those to which the assent of Spartans could be taken for granted and used to underpin the desired conclusion. Divination has this significant, implicit, role in several of the above-mentioned narratives. Implicitly, Leonidas was not acting against Spartan norms in voluntarily taking a small army to its destruction because he trusted a Delphic oracle. (Contrast the reaction that might be expected in our own times if it were shown that a commander in the Second World War had deployed forces in response to astrology.) The conspiracy of Kinadon was said to have been discovered by a mantis acting in his official capacity. Had there not been general respect for such inspired findings, the reference to divination might have induced doubt as to the reality of the affair, inherently obscure as it was. And so above all in the plot alleged against Lysandros; most of the machinations ascribed to the dead general involved the corrupt procuring of oracular sanction for the reform of the kingship. Even if the whole story was an invention of Lysandros' enemies, we still have evidence of a general view among Spartans that statements believed to be from Delphoi and other shrines could be widely persuasive.

\section{Herodotos, Delphoi and Tisamenos}

Investigation of Spartan attitudes to divination may sensibly begin with local retrospect on the Persian Wars of 480-79. For Spartans, as for Athenians, the (ultimately) victorious campaigns of that period were used with hindsight for proud self-definition. The degree of transmitted detail about the anti-Persian campaigns is unsurprisingly great, as compared (for example) with the decades

${ }^{13}$ Xen., Hell. I, 6, 36f.; IV, 3, 13f.; Powell (1989). 
which preceded and followed. And we are readily on guard against patriotic distortions concerning a period in which any ugly failures were particularly likely to be glossed over or excluded from the record. The performance of divination might also be remembered with special interest. For Sparta, as for Athens, Herodotos tells of oracular utterance from Delphoi which drew the attention of military leaders: respectively, Leonidas and Themistokles. There are, however, interesting differences.

According to Herodotos, Delphoi had prophesied to Sparta with explicit ambiguity on the eve of the war (VII, 220): either the Spartans would lose a great and noble city, sacked by 'men descended from Perseus', or Sparta would mourn the death of a king of Heraclid descent, one whom even the strength of lions $(\lambda \varepsilon o ́ v \tau \omega \nu)$ could not hold. Herodotos also reports his belief that Leonidas at Thermopylai, reflecting on this oracle, sent away certain of his allies - and even ordered the army's mantis to leave - so that Sparta might monopolise the glory of the coming defeat which the prophecy implied (and which the mantis, Megistias the Akarnanian, confirmed from sacrificial omens). He suggests, that is, that Leonidas believed the prophecy and its hint as to his own death. Scholars have argued against the historicity of this oracle, on the grounds that it fits too closely the actual outcome of events to be other than an ex eventu composition. The name of one of the Spartan kings (Leonidas) itself referred to a lion, and he in the event was killed by the Persians; the correspondence is too neat. ${ }^{14}$ The Delphic authorities could, of course, have been informed in advance by Spartans that Leonidas would be leader of an exceptionally dangerous campaign, and might have prophesied accordingly. Herodotos says that the prophecy was issued when

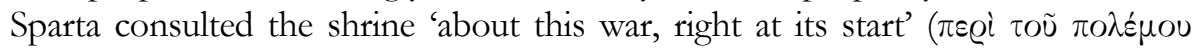

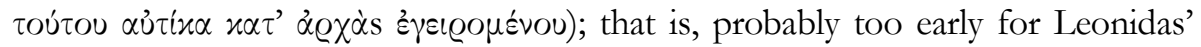
role to be known. But precise chronology is commonly among the first elements to be lost in memory. What makes the prophecy particularly suspicious is the uncharacteristic risk of clear refutation that the oracle would have taken in making it: quite conceivably Sparta would survive unsacked, and Leonidas not be killed. The two outcomes covered too little; in this case the imputed Delphic ambiguity was too precise.

The prophecies which, according to Herodotos (VII, 139-43), were given to Athens by Delphoi make an instructive contrast. They clearly implied the destruction of the Athenian Akropolis, a less bold prediction, since Athens, north of the Isthmos, was more exposed to a Persian army, and the battle of Marathon had given the Persians a special reason for targeting the place vindictively. But more importantly, the oracle is vaguer as to the 'wooden wall' which alone would remain unravaged. Salamis was mentioned, suggesting here too that, if the prophecy was historical, consultation took place at a late stage. (Again, Herodotos

${ }^{14}$ E.g. Parke - Wormell (1956), vol. 1 p. 167 f., vol. 2 p. 44. 
located the consultation much earlier: VII, 145.) But if a naval battle at Salamis had failed, the oracle could protect its credit by claiming that it had meant 'wooden wall' to apply (for example) to flight by sea: the term was quite vague rather than ambiguous as between precise alternatives. In the case of the prophecies reportedly given to Athens, Herodotos has provided elaboratelydetailed context: he tells of the striking circumstances of the consultation, and the desperate pressure applied by the Athenian envoys in the face of initial Delphic pessimism. He names the Pythia and one of the leading men of Delphoi who intervened in the matter: respectively, Aristonike and Timon son of Androboulos (VII, 140f.) - 'Best-victory' and 'Honour son of Manly-counsel', appropriate indeed, well omened - names in the circumstances. And he describes the divergent interpretations which the prophecies received when reported to Athens, to 'the demos', and publicly discussed (VII, 142f.). Themistokles reportedly persuaded the Athenians, against the opinion of the (unofficial) oracle-specialists (khresmo$\log 0 \imath$, that the references to the 'wooden wall' and to Salamis pointed to a successful naval battle. Yet for the hardly less dramatic prophecy supposedly given to Sparta, itself clearer and provocative, there is no corresponding detail as to how the Spartan authorities reacted when it arrived.

To impose an utterly false record of public discussion of sensational material by the Athenian demos might be far harder than to create a false record in the case of Sparta. In accordance with their institutions and ethos, Spartans could explain how their oracle might have become known belatedly and without much detail. They might claim, for example, that the consultation of Delphoi had been performed by the Pythioi, the king's men after all, and that the kings, into whose control the response duly came, had decided not to divulge its contents. Such would be in keeping with Leonidas' noble motives, in going to his death with eyes open, as later believed; it would accord with the general Spartan practice of secrecy, observed by Thucydides $(\mathrm{V}, 68,2)$, and with the manipulation of news in the interest of morale, as later described by Xenophon. Delphoi, which had reason to be pessimistic as the Persians approached, might afterwards happily concur with a false tale which credited the shrine with implicit advice on how the city of Sparta might be saved.

In the aftermath of the Persian Wars, the intelligence of Themistokles (бoyins

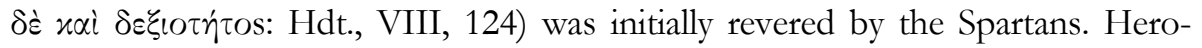
dotos and Athenian speakers at Sparta, reported by Thucydides, attest to his having been honoured by the Spartans more than any other foreigner (Hdt. l.c.; Thuc., I, 74, 1). From Herodotos we also hear, of the period just before the war, that the only non-Spartan whom (with his brother) the Spartans respected enough to make their fellow-citizen was a diviner, whose skills (as we shall see) the Spartans were exceptionally anxious to use as war approached. Since, as Herodotos would later present it, part of Themistokles' mastery of affairs before the arrival of the Persians in Attike was to see and impose the correct interpretation of alarming Delphic prophecy in a military crisis, we might consider the 
possibility that part of the reason for his exceptional welcome at Sparta was his own cleverness in the matter of divination. ${ }^{15}$ It is possible that in the aftermath of the Persian Wars Delphoi and (for a while) Themistokles enjoyed at Sparta a record of having (respectively) issued and interpreted successful divination when it was most needed.

Herodotos, who says almost nothing on the circumstances in which the prophecy concerning Leonidas was uttered at Delphoi, gives much detail about how the Spartans acquired their leading mantis for the war (IX, 33-6). Tisamenos was an Elean of the Iamidai, a clan long esteemed for prophetic skill. Herodotos elsewhere (V, 44f.) tells of an Iamid prophet Kallias, who had been rewarded with lavish grants of land, and so presumably with citizenship also, by the state of Kroton in connection with a war of the late sixth century. Tisamenos was repeatedly invited by Sparta before Xerxes' invasion to issue divination as Sparta's agent; initially, according to Herodotos, the Spartans offered money but, as their fear grew great in the face of imminent Persian attack and they wanted him

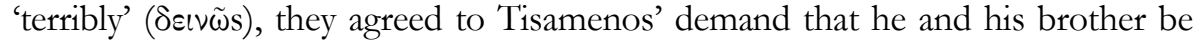
given Spartan citizenship. It is hard to overemphasize the significance of the details we possess on Tisamenos, as they bear on Spartan retrospective attitudes towards him and his craft in Herodotos' time, the second half of the fifth century. The terms which Herodotos uses for Sparta's original invitation may well seem extraordinary, for any state at any period: the Spartans wanted Tisamenos to become 'director of their wars alongside the kings of Heraklid descent' ( $\alpha \mu \alpha$

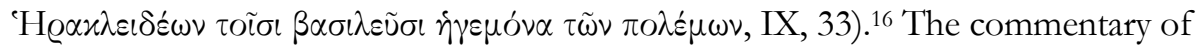
How and Wells (ad loc.) rightly reflects the gravity of this expression, but for that reason recoils from taking it at face-value: 'This cannot mean that the seer was to share the actual command in war, for in comparison with this the grant of citizenship would be nothing. It seems to refer to the position of the kings as priests, since they offered sacrifice before all important undertakings (Xen., L.P., 13). 'Tisamenus was to act with them in this.' Herodotos' picture is indeed remarkable: Sparta - that xenophobe state - wanted a foreigner, one who would advertise his lack of loyalty by negotiating stubbornly and at arm's length with those inviting him, to impinge on the sovereignty of its revered hereditary authorities in matters of life and death for the community. At the root of this Spartan desire was, according to Herodotos, not merely the fact that Tisamenos was an Iamid but also the belief that Delphoi had prophesied that he would win five very great victories. Retrospectively, Tisamenos was thought to have achieved exactly that, in Sparta's interest: the victories were, according to Hero-

15 We might even speculate that one reason for Sparta's possibly inventing a Delphic prophecy about Leonidas was respectful rivalry with Athens, in the matter of strategic prophecy. Rivalry is implicit at Hdt., VIII, 124, where in parallel with the crown of olive given to Themistokles by the Spartans, we hear that a similar crown, but also the aristeia in respect of the naval campaign, were given by Sparta to its own man, Eurybiadas.

16 The point is rightly emphasised by FLOWER (2008), p. $94 \mathrm{f}$. 
dotos, first at Plataia (against the Persians), then at Tegea against Tegeates and Argives, later at Dipaieis against most of the Arkadians, at Isthmos (Ithome?) against the Messenians, and finally at Tanagra against Athenians and Argives (IX, 35). We may see why Spartans could perhaps, with retrospect, unashamedly report that they had trusted profoundly from the start in Tisamenos' competence. And the diviner's record, as remembered, was such as to vindicate his craft for the future in Spartan eyes.

That Herodotos had information from a Spartan source on these matters is strongly suggested by internal details. The historian reports with emphasis that Tisamenos and his brother were the only foreigners ever ( $\mu$ oũvo $\delta \dot{\varepsilon} \delta \dot{\eta}$ ) to have received Spartan citizenship. Of similar form, and similarly likely to be of Spartan origin, is Herodotos' statement elsewhere that Themistokles was 'the only

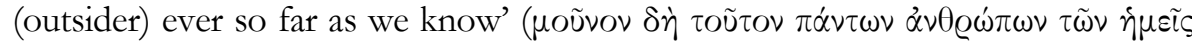
'i $\delta \mu \varepsilon v)$ to have been sent on his way from Sparta with such honours (VIII, 124). Compare the report from the same historian concerning compaigns of the sixth century that the Spartans had 'succeeded in all their other wars and had failed only (uoúvous) against the Tegeans' (I, 65). Statements involving a large claim to historical knowledge, qualified by an admission of a rare exception to an alleged rule, occur with special frequency in Spartan contexts, so much so as to form something like a signature of origin. We think of Thucydides' report that the Spartans were (by their standards) exceptionally hasty in considering severe action in the case of king Agis $(\mathrm{V}, 63,2)$, or indeed of his statement about Sparta's normal judicious slowness - in the context of the official killing of regent Pausanias (I, 132, 5; cf. Plut., Ages., 32). In connection with a report that Spartans on the battlefield (in 418) had become quite exceptionally disoriented by their standards, Thucydides signals his Spartan source explicitly: the event was unique

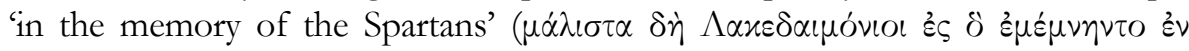

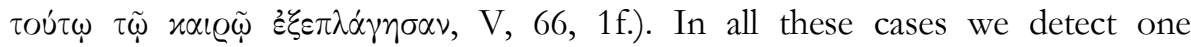
underlying element of apologia: Sparta was a consistently well-run and successful state, in keeping with its claim to have enjoyed the same constitution for centuries. There was homogeneity down the years, as there was among the citizenry, the homoioi, at any one time. Discordant events had to be clearly labelled as rare or unique. So no doubt with the 'unique' grant of citizenship to Tisamenos and his brother, one eminently in need of apology for a state where xenophobia, in the form of xenelasia, could be institutionalised. ${ }^{17}$ The apologia may have gone further. Pindar, in Ol. 6 (27ff.), tells that Iamos, eponymous ancestor of the Elean clan of diviners to which Tisamenos belonged, was born of one Evadne who herself had been conceived and born at Sparta, in a union

\footnotetext{
${ }^{17}$ Aristotle knew of a Spartan tradition according to which foreigners had been admitted as citizens, in the state's early days: Pol., 1270a. One wonders whether the acute oliganthropy of Sparta in his time had commended a change in policy towards granting citizenship, and thus a correspondingly different picture of Spartan history to serve as precedent.
} 
between Poseidon and another eponymous figure, Pitane. Evadne, having as a baby been smuggled from Lakonia to the banks of the Alpheios, was herself as a young woman involved in a second divine union. The composite tale manages to preserve the appropriate origin for the seer Iamos himself, fathered on Evadne by Apollo in or near Elis, with an added element which would have the effect of legitimating the Spartan citizenship of Tisamenos and his brother, as being themselves of Spartan origin. ${ }^{18}$ This ode is dated to 472 or 468 ; at 1.93-96 it mentions Hieron of Syracuse (obit 466) as still alive. It may thus testify indirectly to Spartan reverence of Tisamenos at a period decades earlier than the text of Herodotos. We shall see that relatives of Tisamenos were eminent diviners at Sparta long after the latter's probable time of death; that too attests to the influence of the man in his lifetime.

Herodotos proceeds (IX, 36) to describe Tisamenos' performance as diviner when the Spartans commanded at Plataia; he advised the defensive posture which the Greeks adopted. In this connection (IX, 37) the historian also gives detail about the leading diviner in the enemy camp, another Elean, by the name of Hegesistratos. Again, the account has a Spartan perspective. This Elean, we are told, had previously been caught and condemned to execution by the Spartans

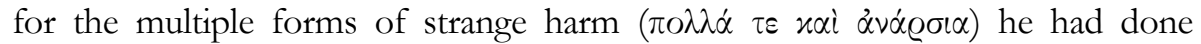
them. ${ }^{19} \mathrm{He}$ had, however, escaped his bonds by cutting off much of his own foot,

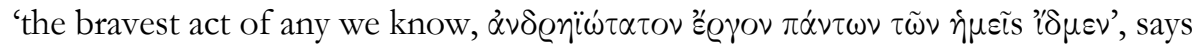
Herodotos. The Spartans went out looking for him 'in full force' ( $\pi \alpha \nu \delta \eta \mu \varepsilon i)$, and were amazed at the daring of the man (Herodotos' admiration, then, matched that of the Spartans). Hegesistratos escaped to Tegea but 'in the end his hatred of the Spartans did not profit him'; for he was caught by the Spartans while acting as mantis on Zakynthos and put to death by them. This story, implying inside knowledge of Sparta as well as a pro-Spartan moral, again seems to reflect belief by Spartan authorities in the formidable powers of an Elean diviner.

\section{Omens and oracles}

It may help at this point to distinguish between the roles - in ancient minds and in our own - of omens and oracles. The two forms of divination were, of course, closely linked in antiquity: the case of Tisamenos shows that the Delphic oracle was supposed to have commended the future work of a mantis acting away from Delphoi, an interpreter of omens such as those which appeared in the form of animal livers. There was good reason for an oracular shrine not to contest the utility of sacrificial and other divination practised far from the shrine. For many purposes, a shrine could not offer the necessary service. Before a campaign, a

18 PARKe (1967), p. 176, citing Wilamowitz.

${ }^{19}$ Flower (2008), p. 80f., well observes that Hegesistratos here is represented not as the prophet of harm to Sparta but as the actual cause of it. 
state might have the time to consult a distant shrine on the grand question of war or peace, or on a general prospect - assuming that the shrine (or the land and sea giving access to it) were not at the time under enemy control. (When Sparta and Athens contested control of Delphoi in the early 440s, at issue was the right of each to precedence in consultation, promanteia, that is the right to consult quickly: Thuc., I, 111, 5; Plut., Peric., 21.) But at short notice, in the face of the enemy, there was usually no question of consulting Delphoi, let alone remote shrines such as those of Dodone or Zeus Ammon. Likewise in the matter of precise timing in a campaign - a key element in the thinking of Spartans in particular. Oracles could hardly pretend to regulate all such things.

Now, in spite of the widespread reluctance of many scholars in earlier generations to engage with ancient testimony to the influence of divination, scholarly monographs were written on oracles: one thinks in particular of the calm and systematic studies by H.W. Parke. Modern cultures are familiar with textual prophecies, in books still held sacred. And metrical prophecies in ancient languages engage our professional competence; we like dealing with such fixed, well-wrought things. ${ }^{20}$ Historians have come more slowly to the study of ancient Greek omens, though there exists now the valuable study of Flower, The seer in ancient Greece (2008). For the modern preference of oracle over omen, a rationalisation is readily available: omens incur from the start insoluble problems of definition. Whether even eclipses were numinous events may well have been contested in the late fifth century. ${ }^{21}$ The point concerning definition is illustrated by an anecdote about a Spartan: when manteis claimed as an omen the discovery of a snake wrapped around a (large) key, he asserted that this was no omen, whereas if the key had wrapped itself around the snake, that would have been.22 However, somewhat similar problems occur with oracular utterances. Not only are modern writers properly exercised by the question of which oracular predictions recorded from antiquity were in fact composed after the event; it is difficult to be sure whether any particular recorded oracular prophecy is genuine. The credit of oracular texts was qualified in antiquity by source-criticism, both subtle, as in Thucydides' remark about the tendency for prophecies to be adjusted retrospectly to suit the supposedly prophesied event (II, 54, 3), and plain, as in Spartan (and Athenian) belief that on occasion corruption had occurred at the

${ }^{20}$ FlOwER (2008), p. 215: 'No aspect of Greek divination has drawn as much scholarly attention as Delphic oracles.'

${ }^{21}$ Thucydides comments at II, 28 on the apparent causal role of the moon in solar eclipses. At VII, 50, 4 he may well hint at a similar physical explanation of lunar eclipses. Plut., Peric., 32, 2 seems to show that divination concerning the heavenly bodies was under challenge from physical theories, near the end of Perikles' life. Plut., Nic., 23, 2 attributes even to the mass of Nikias' Athenian contemporaries in 413 a belief that the moon was somehow responsible for solar eclipses.

22 Plut., Mor. (= Apoph. Lac.), 224e; cf. Cic., De Divinatione II, 62. 
Delphic shrine. ${ }^{23}$ Theognis had written pointedly of the need for theoroi, official reporters of Delphic prophecy, to be utterly honest, neither adding to nor subtracting from the utterance of the shrine. ${ }^{24}$ When Tacitus wrote of mendacio pretium (Hist. IV, 81), reward for lying, he was thinking of reported omens in the Graeco-Roman world, but the phrase might apply to oracles too.

It is perhaps the public effects of recorded prophecies, rather than their origins, which form the more fruitful field of study, though the two cannot be dissociated. And, for this study of ancient reception, omens may well turn out to be the more important category. For, while oracles originated in circumstances which few witnessed, and so were generally open to question, the events which counted as omens were sometimes beyond question and indeed spectacular: eclipses, earthquakes, strange weather, plague are examples. Eclipses, indeed, are for us uniquely privileged among the events recorded by ancient writers, in that their reality and timing can be checked by modern physics. ${ }^{25}$ Thucydides, writing of a Delphic prophecy about Spartan victory in the Peloponnesian War, records it with some reservation, and describes its effect, early in that war, on 'those [Athenians] who knew about it' (II, 54, 4; cf. I, 118, 3; 123, 1f., and below, n. 30). There could, and can, be no such qualification concerning the awareness of Athenian-led troops in Sicily of the total lunar eclipse of 27 th August 413.

Compare Herodotos' account of divination at Athens concerning the Persian invasion. He explicitly gives more weight to an omen than to the Delphic oracle about flight, destruction and a wooden wall: explaining the evacuation of Athens, he writes (VIII, 41): 'they [the Athenians] hurried... wishing to obey the [Delphic] prophecy but mainly for the following reason:...'. And he proceeds to tell of a report, originating with the priestess of Athena, that a large snake which normally lived in the shrine as guardian of the Akropolis, had disappeared; its usual meal of honey-cakes had been left untouched. This was taken by 'the Athenians' as a sign that Athena herself had abandoned the Akropolis. We recall the relative weight given in Herodotos' account to the origins of the Delphic prophecy about the fates of Sparta and Leonidas as compared with his detail on the seer Tisamenos. Was the extent of this concentration on omens perhaps a peculiarity of the historian? Was he perhaps conducting a special defence of omens? Further comment which he makes on the affair of the sacred snake may suggest something very different. He seems to invite doubt as to the reality of the

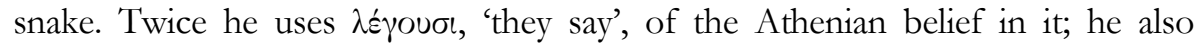
writes, 'and moreover they put out sacrificial offerings to it every month as if it exists' ( $\dot{\omega}$ éóv $\iota$ ). Contrast the assertiveness of a passage (the genuineness of which has been doubted) in which Herodotos defends oracles against disbelief: 'I

${ }^{23}$ Hdt., VI, 66 for Kleomenes believed to have suborned the Pythia to undermine his fellow king Damaratos; on bribery imputed to Pleistoanax, see below.

24 Theognis, 805-10, with FlOwER (2008), p. $218 \mathrm{f}$.

25 STEPHENSON - FATOOHI (2001). 
cannot deny that oracles are true... when I consider such as the following: [text of 8-line hexameter oracle]... When Bakis speaks so clearly on such matters neither do I dare myself to utter an argument challenging oracles nor do I accept such from others' (VIII, 77). In explaining why Athenians might put more faith in an omen concerning an unseen snake than in a reported Delphic prophecy, one should remember an ancient pattern of source-criticism; the integrity of Delphoi was open to challenge, ${ }^{26}$ whereas the report about the snake came from a priestess of Athena, a local official whose goodwill and honesty were far harder to doubt.

Spartan practice in the matter of taking sacrificial omens seems to have evolved in a spirit of source-criticism, to minimise the chance of fraud or of wishful perception. Of Xenophon's time, a century after the Persian invasions of Greece, we read that when a Spartan king sacrifices in connection with a

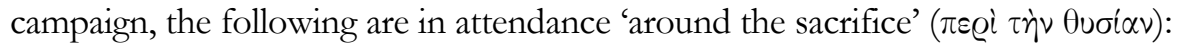

... polemarchs, lokhagoi, pentekonteres, leaders of allied mercenary contingents,

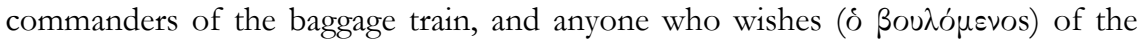
generals of the (allied) cities. Two of the ephors are also present; they do not act in

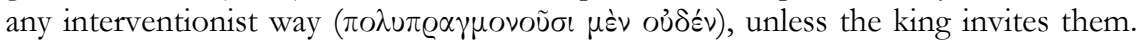
But their presence, watching what each person does, keeps everyone in order, as one would expect. And when the sacrifice is completed, the king summons everyone and gives out the commands. If you saw all this, you would think that in military matters all other peoples were mere improvisers, while the Spartans alone were true military specialists (Lak. Pol., 13, 4f.).

This picture of Spartan practice is highly revealing, but it too must be treated critically, with a view to its author's context and intentions. In the first place, Xenophon may have been writing in conscious defence of the king for whom he composed a formal eulogy (the Agesilaos). Agesilaos (king from 400 to 360) was for decades the most powerful individual at Sparta, and thus was eminently exposed to criticism in that officially levelling culture. Elsewhere in our present text, the Lak. Pol., Xenophon insists on the claim that at Sparta, unlike other Greek cities, the 'most powerful' (i.e. the hereditary rich) act with proper deference towards the officers appointed by the city (VIII, 2). Plutarch in his Agesilaos (ch. 4) represents that king as eagerly hurrying to obey the ephors, or rising to his feet in deference to them. Such statements of ideal implicitly suggest a criticism: the power of Agesilaos meant that he might have disobeyed if he wished, perhaps indeed that he did on occasion allegedly overstep the mark. Similarly with the ephors: they did not act at sacrifices in interventionist fashion.

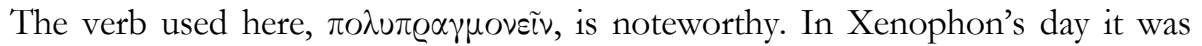
pungently pejorative: $\pi \circ \lambda \cup \pi \varrho \alpha \gamma \mu o \sigma \dot{v} \eta$ had been, for many, a besetting fault of

${ }^{26}$ Hdt., V, 63 for 'the Athenians' stating that their own Alkmaionid aristocrats had been successful in bribing the Pythia, who accordingly urged Sparta to free Athens, that is, to evict the Peisistratid tyranny. 
the Athenian demokratia and its empire. ${ }^{27}$ Here Xenophon, in stating that the ephors did not impinge upon the king's prerogative, reveals with his lively word a lively concern. Xenophon's text has, then, an idealising insistence on institutional balance: a king's power over divination was limited by that of ephors and others, while the ephors themselves duly respected the king's prerogative. Whether matters were in reality quite so well adjusted we may doubt. But Xenophon's elaborate description does imply that suspicion directed against royal misuse of divination was great enough to engender elaborate countermeasures in the form of observation by numerous officers of state.

Commenting on the present passage of Xenophon, Parker writes:

... insistent though Xenophon is that this is a truly public examination of entrails, there is no doubt that the dominant figure at the ceremony is the king. In this passage Xenophon simply fails to mention the professional seer who must have provided the formal interpretation of the sacrifice. The rite was in theory public and objective, in practice under the close supervision of the king... the whole conduct of the ceremony lessened the likelihood of serious conflict between human and divine will (1989, p. 157).

This argument is important for the rationalising element in Parker's work. It may, however, be challenged, not least in respect of the omitted seer. ${ }^{28}$ Xenophon was not writing in an anthropological spirit. His Lak. Pol. has as its advertised aim to explain the uniqueness of Sparta's success (I, 1), and is accordingly structured around points of contrast between Sparta and other Greek states. Two instances of such have already been noted: the Spartans as uniquely specialised in war, and their kings as unusually obedient to other officials, as compared with (rich) Greeks elsewhere. There are many other references in the work to such supposed differences. ${ }^{29}$ Indeed the treatise opens with the claim that the Spartan lawgiver, Lykourgos, proceeded 'not by imitating the other citystates but by having opposite ideas to most of them' (I, 2). If, therefore, Sparta resembled other city states in allowing a mantis a dominant role at sacrifices, that would not have advanced Xenophon's main thesis and might for that reason have been passed over without comment, as being banal and readily inferred. It is possible that the relations of seer and dyarch were not always what secularising modern scholars may assume them to have been. And in particular one may suspect that the influence of a Spartan king in prophetic matters was not the

27 Perikles, in an anti-Spartan context, is shown implicitly rebutting the charge of $\pi 0 \lambda u-$ $\pi \varrho \alpha \gamma \mu$ бóv $\eta$ against Athens, by refusing to give a positive value to an opposite term, $\alpha \pi \varrho \alpha \dot{\gamma} \mu \omega \nu$ : Thuc., II, 40, 2.

28 On the point of a 'truly public' sacrifice, we should not be misled by Xenophon's use of the term o $\beta o u \lambda o ́ \mu \varepsilon v o s$. In an Athenian context that phrase might indeed suggest that any citizen was free to participate. But in the Spartan context described here by Xenophon there is no

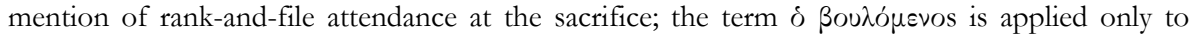
'generals from the (allied) cities'.

${ }^{29}$ E.g. I, 10; II, 12f.; III, 1; IV, 7; V, 2; V, 5; VI, 1; VI, 4; VII, 1; X, 4; XV, 1. 
same in the early fifth century as it was a century later, during the long ascendancy of Agesilaos. In any case, the above-quoted passage of Xenophon implies that the interpretation of sacrificial entrails might be contested in the early fourth century, as between king, ephors and others. The very possibility of such contest might give to the mantis a certain influence, a chance to manoeuvre as between the different parties.

\section{Divination and the Spartan constitution}

Measurements conducted in fairly recent times (on the British population during the Second World War) ${ }^{30}$ bear out remarkably the suggestion made by an Athenian speaker in Thucydides, ${ }^{31}$ and amplified by the latter's narrative, that the influence of divination (or, in the modern case, of astrology) is greatest when secular arguments yield least security. Compare Herodotos on the way great fear of the Persian invasion impelled Sparta to employ Tisamenos. In crises, arguments from the supernatural may supply hope when other calculations tend to pessimism. ${ }^{32}$ Behind Sparta's insistent claims to have a stable constitution ( $c$. Xen., Lak. Pol., 15, 1 on the kingship) lay nervousness. Fear for the Spartan constitution is itself particularly evident at times of military crisis. In the late $420 \mathrm{~s}$, when Thucydides shows the Spartan authorities in a state of near-panic over their military setbacks (IV, 55, 3f.), Sparta disfranchised some 120 of her own citizenwarriors, many of them of leading families, merely as a precaution $(\mathrm{V}, 15,1 ; 34$, 2). It was evidently feared that these men, who had allowed themselves to be taken prisoner at Sphakteria in breach of what we may call the 'ethic of Thermopylai', might react to the moral cloud hanging over them (and thus to their own reduced prospects of social advancement at Sparta) by contriving a revolution. It might well also have been wondered whether some of these men, who had spent several years under Athenian control as prisoners, might (to use Greek idiom) be 'thinking Athenian thoughts': that is, might be inclined to compound with the enemy. Half a century later, when Sparta, having lost her hegemony and much of her citizen army at Leuktra, was facing an unprecedented invasion of her home villages by the victorious Theban-led army, we hear that the Spartan authorities led by Agesilaos turned on and killed a sizeable group of Spartiates believed to be

30 MASS-OBSERVATION (1947), p. 60: the credit of astrology was highest, affecting almost half of the sampled population, when secular forecasts were bleakest. As the prospect of winning the war improved, avowed faith in astrology fell off sharply.

31 Thuc., V, 103, 2; Antiphon, 5, 81; Xen., Hipparch., 9, 8f. I cannot agree with the view of FLOWER (2008), p. 17, that Thucydides does not reflect the general Greek tendency to perceive omens in times of crisis.

32 Greek divination should not, however, be seen as simply therapeutic: Thucydides' account of the last days of the Sicilian expedition shows that popular religious prophecies then conduced to self-recrimination, pessimism and a fear of imminent destruction: POWELL (1979a), p. 28f. On Sparta similarly, PARKER (1989), p. 161. 
planning revolution. ${ }^{33}$ In this crisis, too, it would be rational to fear that some might prefer to deal with the ascendant enemy by negotiation, even if treasonable, rather than by warfare. We might well ask, accordingly, how confident Spartans were in their own constitutional solidity, in the competence and loyalty of their own leaders, in the crisis posed by the Persian invasion of $480-$ especially if there were divisions on policy. And if there were good reasons to be fearful on this score, divination might have its role to play in the constitutional as well as the military area.

The years around 480 were, for the standing of the Spartan kingship, deeply but not exceptionally - unstable. The most memorable of recent dyarchs, Kleomenes, had come to a violent end at Sparta (490), after a period of exile in which he is recorded as having organised anti-Spartan moves among the Arkadians (Hdt., VI, 74). Whether or not he died by suicide, as seemingly in the official account (colourfully detailed: Hdt., VI, 75), the enmity of other leading Spartans towards him is clear. ${ }^{34}$ Damaratos, the dyarch whose ejection Kleomenes had earlier secured with the aid of Delphic divination (Hdt., VI, 66), had gone over to the Persians, and is recorded by Herodotos as having accompanied them on their invasion (e.g. VII, 101). He had been keenly pursued across Greece at the beginning of his exile, in a way which may suggest that the Spartan authorities planned to kill him (Hdt., VI, 70): subsequently other exiled kings, Pleistoanax and (in the early fourth century) Pausanias, are recorded as living in sanctuary, in an attempt to use Sparta's religious inhibitions to restrain the state's possibly lethal intentions. In the aftermath of the Persian invasion, Damaratos' successor, king Leotykhidas, victorious commander at the battle of Mykale, was exiled for taking a bribe in the enemy, Thessalian, interest (Hdt., VI, 72). Earlier in his eventful life he had been handed over, by a Spartan court, to the control of his enemies the authorities of Aigina (Hdt., VI, 85). And the regent Pausanias, victor at Plataia, would be brought to his death by the Spartan authorities, accused of plotting with Persia and for a revolution involving Sparta's helots (Thuc., I, 95, 128-34). It is hard to imagine evidence of greater suspicion towards Sparta's hereditary dyarchs - short of actual overthrow of the institution.

If we believe that Sparta's transition to an austere constitution was at this period still quite recent, as has been suggested by Lakonian vase-painting of the mid-sixth century with its scenes of luxury and social division, we should perhaps also wonder whether the rough treatment of the dyarchs around 480 was not a case of revolution manquée. 35 The dyarchs did not fit the austere system. They

\footnotetext{
33 Plut., Ages., 32 with Cartledge (1987), p. 164.

${ }^{34}$ Hdt., VI, 82 for the trial of Kleomenes, at the initiative of 'his personal enemies' ( $\varepsilon^{\prime} \chi 00$ ) on a charge of having been bribed into favouring Argos; VI, 66, 74 for the influence at Sparta of the belief that Kleomenes had by trickery at Delphoi contrived the exile of his fellow-dyarch Damaratos.

35 POWELL (1998).
} 
were an anomaly among the homoioi. Their position would inevitably recall the ancien régime. Their heirs-apparent seemingly did not participate in the homogenising Spartan education. ${ }^{36}$ A noteworthy quality of classical Sparta, perhaps the most important one for explaining Sparta's success under its austere regime, was specialism. We recall Xenophon's words about the Spartans as the only true military specialists, or his description of the martial images produced under Agesilaos at Ephesos as resembling a 'workshop of war'. ${ }^{37}$ Some Spartan homoioi had a further specialism, passed from father to son, as heralds, aulos-players or cook-sacrificers. ${ }^{38}$ Yet here too the dyarchs compared awkwardly. Excluded as they might be from the militaristic education system, they were nonetheless Sparta's senior generals. As members of the gerousia they had an enduring role in civilian politics. And then there was their control over military sacrifices and aspects of Delphic prophecy. Aristotle would describe the dyarchs as hereditary generals (Pol., 1285b). We might wonder whether many Spartans might rather see them as hereditary generalists, and in this way too might resent them as misfits under the austere system. Such thoughts perhaps allow us better to evaluate Herodotos' striking words on the Spartans' reasons for seeking out the Iamid diviner Tisamenos: that they wanted him to be 'director of their wars alongside the kings of Heraklid descent'. Not only is this (as Herodotos makes clear) a case of recourse to divination in a military crisis. It also shows Spartans seeking to deal with the frighteningly anomalous, generalist dyarchs by bringing in a specialist. Elis was clearly famed for its diviners; the case of the Elean seer Hegesistratos, dreaded at Sparta around the time of the Persian invasion, makes the point, perversely but clearly. And the Iamidai, to which Tisamenos belonged, followed a family tradition of specialism ${ }^{39}$ like Sparta's own specialist heralds, aulos-players and cook-sacrificers. Tisamenos' Elean origins were indeed in marked tension with Sparta's general mistrust of outsiders. But his specialism chimed exactly with the Lakonian austere system.

It may be worth speculating briefly about how the then dyarchs Leotykhidas and Leonidas might have reacted to Tisamenos' appointment. On the face of it, they might be expected to oppose the sharing of their military authority (as Herodotos describes it) with this newcomer. Whether these kings were temperamentally such as to welcome guidance in the coming exceptional danger we cannot guess. But each might have understood, following the royal careers of Damaratos and Kleomenes, that other Spartan authorities might doubt their integrity. King Leotykhidas had already received an unforgettable lesson in the matter, when handed over to the control of the Aiginetans, whom he had

\footnotetext{
36 Plut., Ages., 1.

${ }^{37}$ Xen., Ages., 1, 26; Hell. III, 4, 17.

38 Hdt., VI, 60; BerThiaume (1976).

39 On the importance for manteis of being descended from a line of such prophets, FLOWER
} (2008), p. 45-47. 
offended (Hdt., VI, 85). On the eve of Xerxes' invasion it might indeed be politic for royalty to give way, rather in the spirit of the legendary Spartan king Theopompos who supposedly had acquiesced in the foundation of the ephorate, limiting the dyarchy in order to preserve it (Ar., Pol., 1313a). And if royalty in 480 felt pain at making concession to non-royal authorities at Sparta, it might even be, for reasons familiar in arbitration, that Tisamenos' status as outsider reduced the pain; he at least was not one of those Spartans who had in recent times acted severely against Damaratos, Kleomenes or Leotykhidas.

\section{Earthquake and helot revolt}

In (or near) 465/4 the Spartans were struck by what Thucydides was to describe simply as 'the great earthquake' $(\mathrm{I}, 128,1)$. He gives (ibid.) the reason why the earthquake occurred, 'as they [the Spartans] think'; the present tense is

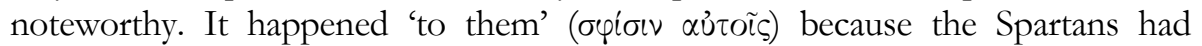
removed helot suppliants from the shrine of Poseidon and killed them. It was, for Thucydides' Greek readership, unnecessary to explain that Poseidon was the god of earthquake.

This event, long remembered as we see, involved for Sparta two intimate disasters. Later accounts stressed the damage in the vital area of citizen numbers. ${ }^{40}$ And there was a widespread revolt of the Messenian helots, in accordance with the principle later formulated by Aristotle, that the helots 'lie in wait, as it were, for disasters' affecting the Spartans (Thuc., I, 101, 2 - 103, 3; Ar., Pol., 1269a). Here was opportunity for unusually persuasive divination: an event had occurred of a kind traditionally seen as numinous, ${ }^{41}$ and a plausible explanation was available for it: a sin against the relevant god committed by the community which especially suffered from the supernatural event.

Comparable is the Athenians' reaction when unseasonal (as they thought) weather afflicted their retreat from Syracuse: they thought that 'this too' (in addition to the lunar eclipse - and much else) had been sent to destroy them (Thuc., VII, 79, 3). And here too there was a supposed sin available to explain the divine hostility. Nikias in 413 is reported by Thucydides as suggesting to his demoralised men that Athens' action in attacking Syracuse might indeed have attracted divine punishment (though he argued that any such punishment was likely already to have reached its limit: Thuc., VII, 77, 1-3). In both cases, the Spartan and the Athenian, there had not of course been faith in the generalisation "such-actions-as-this-are-unholy-and-will-be-heavily-punished-by-divinity"

40 HODKINSON (2000), p. 417f. for ancient references and modern analysis. CARTLEDGE (1976) argues for a connection between the seismicity of Lakonia and the strength of Spartan interest in divination.

41 Compare the phrase of Xenophon used of a later occasion: 'the god shook the earth', Hell. IV, 7, 4. 
sufficient to deter the relevant action in the first place. But, in both cases, the religious interpretation would be made plausible in retrospect by a set of unusual events pointing in the one direction. The earthquake was rare in its severity, witness Thucydides' phrase 'the great earthquake'. Similarly he would describe the fate of the vast Athenian expedition against Syracuse as unique in its scale and thoroughness (VII, 87, 5f.). And in each case the human agents who inflicted much of the supposed punishment were clearly in a sense the same people as had been the victims of the original supposed offence. It was Syracuse which had crushed the Athenian fleet and was realistically expected to crush in turn the land force. And, in Sparta's case, the helot revolt ultimately proved incapable of suppression.

Thucydides does not say that Sparta immediately after the earthquake accepted that the killing of the suppliants had caused it. His use of the present tense applies to Spartan belief in his own day and no doubt during some earlier period which he does not specify. Tisamenos, we recall, was credited with helping to produce a great victory for the Spartans against the Messenians at 'Isthmos' (or perhaps 'Ithome'). In any case, the position which Herodotos assigns to this victory, in his chronologically-ordered list, is somewhere between the battles of Plataia (479) and of Tanagra (458 or 457); the timing is thus appropriate for the Messenian revolt which followed the great earthquake. Now, even if Spartans had, shortly after the earthquake, reflected on their own possible responsibility for it, a mighty victory over the Messenians, such as Herodotos records, would have severely interfered with any such religious interpretation. But helping to establish the religious interpretation as Spartan orthodoxy was the success of the Messenians in holding out against the Spartans for many years on Mount Ithome. In explaining why the Spartans, after this long war, let the rebel Messenians go, Thucydides records that 'the Lakedaimonians had had in their possession for

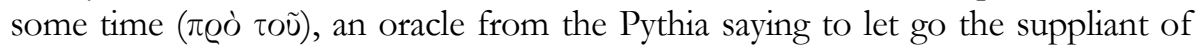
Zeus of Ithome' (I, 103, 2). Here the indication of when this oracle supposedly was issued is of great significance. Sparta evidently could not claim that it had been issued at the time when the helots were in fact released. Accordingly the possibility of fraud should arise in our minds; it would also probably occur to some of the Spartans themselves, to those, that is, who were not privy to any manipulation. In mentioning not the issuing of the oracle but the possession of it, Thucydides' description should make us think of the dyarchs' store of Delphic prophecies. The reference to releasing a suppliant of Zeus corresponded nicely with the supposed offence of killing suppliants, those of Poseidon, his brother: the oracle showed the Spartans how to restore relations with divinity by symbolically reversing their behaviour.

The diplomatic utility of this alleged oracle is obvious. It minimised the loss of face on the part of the Spartan state, which now could claim that the (unforgettable) concession to the rebels was not the result of weakness. The worst precedent had not been set. Any helots thinking of revolt in the future could not rely on the 
thought that predecessors in that role had been invincible. The supposed oracle about Ithome appears to resemble that concerning the Persian invasion and Leonidas: it both significantly lacks a detailed origin and helped to pass off in retrospect a Spartan military defeat as divinely ordained, indeed as an act of virtue. During this episode, firmer religious convictions in the Spartans probably arose from publicly-known events imputable to divinity, the earthquake and consequent revolt. Interpreting such would appropriately be the work of a mantis on the spot. Interestingly, Pausanias the Periegete would write, centuries later, that the Spartans took their decision to release the helots 'obeying Tisamenos and the oracle at Delphoi' (III, 11, 8). We notice that he mentions Tisamenos before Delphoi, something that he is unlikely to have done inadvertently. If Tisamenos, with his revered record of advice about earlier victories, had effectively urged the Spartans not to press for outright victory this time, his words were likely to be taken very seriously. On this occasion, indeed, his prophecy might be an easy one: not only would he very likely know what the Spartans wished him to say, but his forecast, rather than being refutable by events, was quite likely to be selffulfilling.

\section{Thucydides, Delphoi and the credit of kings}

At the start of the Peloponnesian War, religious considerations were promising for Sparta. The oracle at Delphoi had this time almost certainly been consulted; Thucydides places the consultation between Sparta's decision in principle for war and the outbreak of hostilities. The god of Delphoi had responded that victory would come to the Spartans if they fought to the best of their ability ( $\varkappa \alpha \tau \dot{\alpha}$

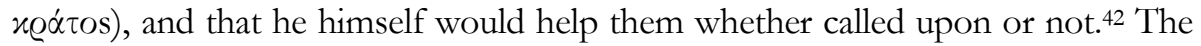
text which Thucydides guardedly reports is highly plausible, if only as an example of prophetic art. The first element of this prophecy realistically insured Delphoi against public refutation by events. If Sparta did not win, Sparta's own defects

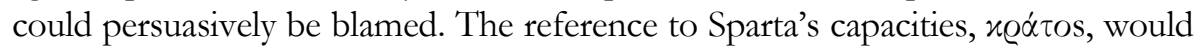
appeal to Spartan vanity. Indeed, the first element of the prophecy matched the standard psychology of defeat. Losers blame their own defects more commonly than they point to enemy virtues. Such is more in keeping with renascent optimism. One can hope to alter one's own performance more readily than that of an enemy. The second element, concerning Apollo's own partisanship (he needed no invitation to smite Athens), is itself realistic in the circumstances.

42 Thuc., 1, 118, 3; 123, 1f.; II, 54, 4f. In the first passage Thucydides will not take responsibility for the reality of the prophecy, but uses the qualifying phrase 'as is said' ( $\dot{\varsigma} \lambda \varepsilon \dot{\varepsilon} \gamma \varepsilon \tau \alpha)$. In the

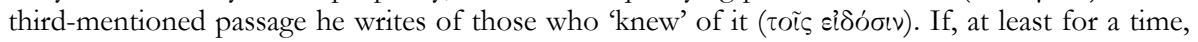
Thucydides who had been a well-placed Athenian politician in the early 420 s was unsure of the reality of this most significant contemporary utterance of Delphoi, we should conclude that there probably existed very widespread ignorance and doubt about prophecies from the most esteemed shrine of Greece. 
Whereas Sparta in the early 440s had intervened militarily to restore control of Delphoi to native authorities, Athens had mounted an intervention of its own shortly afterwards to put the shrine back under the control of its then ally Phokis. ${ }^{43}$ So Thucydides records $(I, 112,5)$, with the brevity which he characteristically applies to notices of religion at work in politics. ${ }^{44}$ Following Athens' definitive loss of power in Central Greece shortly afterwards, through the battle of Koroneia (447 or 446), it is virtually certain that the oracle was by 431 firmly under the control of native Delphians with an interest in favouring Sparta over Athens.

Early in the Peloponnesian War the credit of the Delphic oracle must have been high at Sparta. For plague ravaged Athens, twice, destroying a large minority of the population. Thucydides observes that the plague, so spectacularly contagious among the Athenians (it spread to the Athenian force besieging distant Poteidaia and ravaged that too: II, 58), barely affected the Peloponnese. He makes this observation in the context of Athenian concern that the plague was divinely sent, in accordance with the Delphic prophecy. Writing of 'those [Athenians] who knew of the Spartans' prophecy', he states: 'they thought that events were closely matching the prophecy: the plague had started as soon as the Peloponnesians had invaded [Attike], and while it had not affected the Peloponnese to any significant extent, its worst effects had been in Athens...' (II, 54, 4-5). The plague would readily be seen as Apollo's work for a reason which, for a Greek readership, Thucydides had no need to make explicit. Apollo was traditionally seen as the sender of disease: the Iliad had memorably opened with the god in that role (I, 43ff.). Thucydides reports Perikles himself, when explaining near the end of his life why some Athenians 'hated' him, as referring to the

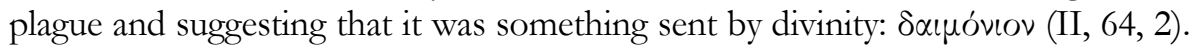
If Athenians accepted the depressing thought that the god was against them and

43 Plutarch, who was to be a priest of Delphoi in the second century AD, adds that Sparta on this occasion recorded the privilege of prior consultation, promanteia, which it thereby secured in an inscription on the side of a bronze statue of a wolf at Delphoi. Athens riposted by inscribing the wolf's other side with a reference to promanteia of its own: Peric., 21.

44 Compare the new, and bare, information which Thucydides gives at 8.1.1, after reporting in very great detail the history of the Sicilian expedition: that oracle-specialists, manteis and others employing divination had 'made the Athenians hope ( $\varepsilon \pi \dot{\eta} \lambda \tau \iota \sigma \alpha \nu)$ to capture Sicily' ( $c f$. POWELL 1979a). Hornblower rightly describes this as 'a huge analepsis' (2009, 257). Our knowledge of Greek divination suffers, as Hornblower observes, from 'the many religious silences of Thucydides' (1991, 183). He writes elsewhere (1992, 170), 'The religious silences of Thucydides are in their way quite as scandalous as the political silences of Xenophon, for which he is so often denounced.' While not radically disagreeing, we may note that Thucydides' clearly-signalled disrespect for political divination (on which POWELL 1979b) prevents any suspicion that he might have written, as Herodotos and later Greeks may have done, to commend religious prophecy as a guide to action. That Thucydides tends - for the history of Athens perhaps more thoroughly than for that of Sparta - to play down divination, and to admit its influence through gritted teeth, has the useful effect, perhaps intended, of confirming for the reader the reality of such credulous behaviour as he does record. 
with Sparta, we should reckon that the same considerations which brought the Athenians to that view would impress Spartans above all. A distinguishing element of their culture was its resistance to wishful thinking in the identification of military opportunities. ${ }^{45}$ But even they were subject to mood-swings, as we shall now see.

As the Archidamian War lengthened, Spartan hopes declined. Athenian commanders were consistent, Perikles and his successors alike, in denying to Sparta the full-scale land battle which would have played to her strength. Regular invasions of Attike and destruction of crops had not brought Athens to her knees. Sparta's essays at naval power had failed, and with the capture of some 120 Spartan citizens on Sphakteria in 425 the Athenians acquired hostages of high status. Fear for their fate precluded further assaults on Attike. Sparta's military reputation abroad, on which depended her capacity to attract and mobilise allies, was damaged by the suspicion that the Spartans had 'gone soft' ( $\mu \alpha \lambda \alpha x i \alpha \nu$, Thuc., $\mathrm{V}, 75,3)$. As Athens seized Kythera, the large and strategic island off southern Lakonia, Sparta had cause to fear a helot uprising. Thucydides reports, in summary and in detail, that Sparta came close to panic. To recover the citizenprisoners, repeated and unsuccessful offers were made to Athens to end the war. In the process of demoralisation, religious prophecy was again involved. The Delphic prophecy about the war might now seem to fit events even more convincingly than it had when the plague hit Athens. For Apollo had also suggested that, if Sparta did not fight its best, the war might (or would) not be won. And here was a plausible case of decline in standards, the group surrender on Sphakteria, which was making necessary an implicit diplomatic admission that the war had not been won.

It may be possible to trace in Thucydides signs of acute Spartan dependence on Delphoi in this period, the 420s. Another Spartan king, expelled long before in circumstances of extreme prejudice, became awkwardly relevant once more. King Pleistoanax, who had led an invasion of Attike in 446 which did not lead to victory, or indeed to battle, had then been exiled on a charge of bribery (Thuc., V, 16, 3). That the charge was realistic, that it might have convinced and incensed numerous Spartans, is suggested not just by information from the Athenian side of unspecified special expenditure in this connection, ${ }^{46}$ but by Thucydides' report that in exile Pleistoanax, surely well informed, felt it wise to live in a building which lay partly within a religious sanctuary, the shrine of Zeus at Mount Lykaion in Arkadia - 'for fear of the Spartans'. He evidently reckoned that his mere exile would not satisfy all, that he might be mercilessly pursued abroad as his predecessor Damaratos had been, but that as a suppliant of Zeus he might be protected from Spartan wrath for the same religious reason that Sparta had invoked in the 450s for not killing the helots of Mount Ithome, themselves

\footnotetext{
45 POWELL (1980).

46 Plut., Peric., 22f.; Ar., Clouds, 859 with scholia.
} 
'suppliants of Zeus'. Now 'in the $19^{\text {th }}$ year' of his exile (427 or thereabouts) Pleistoanax was allowed to return to Sparta, and was accorded extreme and public evidence that his status there would thenceforward be of the highest. His return was to be greeted with 'the same choruses and sacrifices as when they first established the kings at the foundation of Lakedaimon' (V, 16, 3). Thucydides' phrase implies that he was trusting a Spartan source; grammatically, the construction reflects reported speech, part of the narrative constructed against Pleistoanax by his Spartan opponents. Who but Spartans would be thought to know about such remote details of internal Spartan history? How characteristic it was of Spartans to stress the continuity of Lacedaemonian history over a vast period! Pleistoanax would be no mere figurehead. Thucydides sees his disposition for peace as a main reason for Sparta's détente with Athens in 421 (V, 16-17, 1; cf. V, 33,$1 ; 75,1$ for his subsequent military commands). Now, to restore to a position at the head of the state a man who had much reason to be vengeful towards those who had driven him into exile, in such humiliating and frightening circumstances and for so long, clearly threatened stasis. And Sparta, as her whole history shows, was by Greek standards exceptionally - even though not consistently - anxious to avoid civil strife. The restored Pleistoanax would have

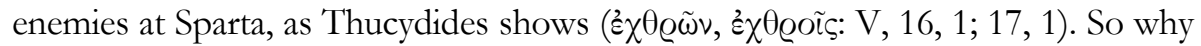
did the Spartans now think it necessary to take the risk of restoring this tainted man?

Thucydides mentions only one reason, and it concerns religion. The Delphic oracle had told the Spartans to 'bring back the seed of the semi-divine son of Zeus from the foreign land to his own. Otherwise they would plough with a silver ploughshare'. The descendant of Zeus in question would be taken to be the exiled king (the two royal families claimed, like certain other Spartans, descent from Herakles, the demigod son of Zeus), and the point about a silver ploughshare presumably meant to act wastefully or in vain. The softness of the metal might have been meant to allude not only to inefficient ploughing but to military ineffectiveness, 'softness' as $\mu \alpha \lambda \alpha x i \alpha$. Thucydides' words in reporting this Delphic instruction are ... he [Pleistoanax] and his brother Aristokles had induced the prophetess at Delphoi, so they [Pleistoanax' enemies] claimed, to respond over a

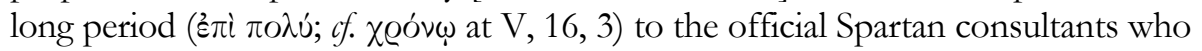
arrived that they should bring back the seed etc.' ( $, 16,2) \cdot{ }^{47}$ In Thucydides' brief

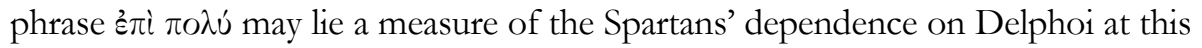
period. Again and again they consulted the shrine. ${ }^{48}$ If, as seems quite likely, the consultations in question belong to the years immediately preceding the actual restoration, one could readily explain why Delphic disapproval, or non-co-

47 The episode recalls Herodotos' account of repeated instructions to Sparta from an earlier bribed Pythia, to eject the Peisistratid tyranny; above, n. 26.

${ }^{48}$ If each time the only response they got concerned the restoration of Pleistoanax, one effect would have been to deprive them of advice on whatever other matters they were anxiously raising. 
operation, might matter so much to Spartans as to persuade them to restore the troublesome exile. The Delphic god in the period 430-27 would be thought prescient and powerful; he had foretold and carried out his own intervention in the form of the plague, but he knew about another condition which was needed for Spartan victory. By doing what did Sparta have to show that she was fighting 'according to her might'? One can readily imagine Sparta thinking it worth pressing Delphoi on this subject, and taking very seriously the condition about restoring Pleistoanax.

After the restoration was effected, things continued to go wrong for Sparta. Indeed, matters after 425 went far worse. According to Thucydides (still reporting the accusations of Pleistoanax' enemies), 'Pleistoanax was maliciously accused by his enemies in connection with his restoration; whenever the Spartans failed in anything, those enemies regularly ( $\alpha i \varepsilon i$ ) held him up to the Spartans as the person responsible: according to them, things were going wrong because his restoration had been procured by illicit means.' And there follows the accusation about suborning the Pythia. The exiled king, that is, had employed an oracle in his own defence. The Spartan authorities had accepted it in part, at least, because of the credit the oracle had acquired from its apparent link with a numinous event, the plague. And now against the king, and indeed against the credit of the Delphic priestess, the king's enemies were invoking other events interpreted as divinelysent, namely Sparta's failures in the war. Again we notice in Thucydides a subtle indication of the frequency of this divination: it happened 'regularly', 'whenever' there was a setback. Spartans were clearly impressed by this set of accusations. According to Thucydides, it was to get rid of the criticism that Pleistoanax sought a period of peace. In peacetime there was less reason to expect disasters that enemies could exploit politically against himself $(\mathrm{V}, 17,1)$.

Spartan consistency in interpreting setbacks as divine punishment emerges from a further passage of Thucydides. At VII, 18, 2-3 he describes the Spartans' attitude in $414 / 3$ as they prepared to recommence invasion of Attike. They contrasted the present situation, in which Athens seemed to have been the first to break the treaty, with the beginning of the Archidamian War. Then it had been they, the Spartans, who rejected arbitration. This, as they saw it in retrospect, had been a formal offence ( $\pi \alpha \varrho \alpha \nu o ́ \mu \eta \mu \alpha$, used twice) of their own, their own fault ( had proceeded from their side. Whereas it had been stipulated in the treaty then applying that there should be no fighting if one side were willing to submit to arbitration, they had not heeded Athens' call for such. For these reasons they

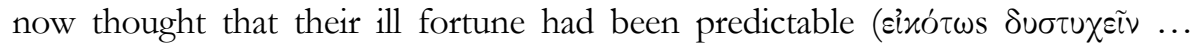

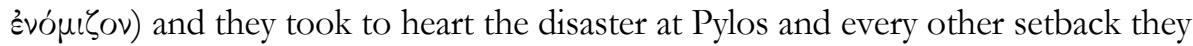
had suffered. The word which Thucydides here uses for 'took to heart',

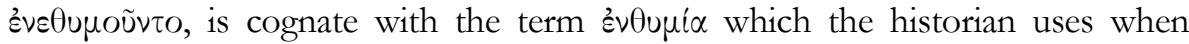
describing the link repeatedly made by Pleistoanax' enemies between the alleged illicit action $(\pi \alpha \varrho \alpha \nu o \mu \eta \theta \varepsilon i \sigma \alpha \nu)$ of the king towards the Delphic oracle and the 
setbacks suffered by Sparta. When in Sicily, later in 413, it was the Athenians' turn to do pessimistic divination in a climate of guilt, Thucydides' phrase is

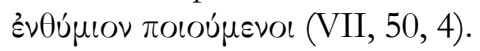

The Spartans' idea that they had been wrong to embark without arbitration on war against Athens in 431 raises a question about the credit of the Delphic prophecy issued at that time. How could the morality of the war be doubted if Apollo himself had been so emphatically belligerent on the Spartans' side? How could the god have, albeit conditionally, predicted Spartan victory (above, n. 42) if Sparta's faults were going predictably (iંxó $\tau \omega s$ ) to lead to a bad outcome? We might observe first that divinatory thinking is no more likely to be free of confusion than is thinking along purely secular lines. Thoughtful divination might remember the divisions between the gods in the Iliad: plague-sending Apollo had then supported the side which lost, the side which did not evidently have right on its side. Divisions between Apollo and his father Zeus were still conceivable; though when, after the Peloponnesian War, a Spartan king asked Delphoi whether Apollo was in agreement with a divinatory response already issued by 'his father' Zeus at Olympia (Xen., Hell. IV, 7, 2; Ar., Rhet., 1398b), his purpose was probably to apply pressure, to exploit a presumption that Delphic Apollo would represent, as usual, the will of Zeus. In seeking to explain why by $414 / 3$ Apollo's support of eighteen years earlier had apparently little remaining moral force, we might be tempted to invoke simple passage of time. But again we remember how an oracle apparently far from new or of clear origin had been deployed by Spartan authorities to justify letting go the helots of Mt. Ithome. Quite likely the accusations of the 420s, not universally persuasive but (as we have seen) seriously influential, that Pleistoanax had improperly elicited a prophecy from the Pythia, had reduced the shrine's credibility. But perhaps something more general was involved.

The authenticity of prophecies from distant shrines was always beyond the capacity of most to perceive. Oracles from Delphoi passed to Sparta along channels controlled by royalty, and the credit of kings at Sparta was, for many in our period, frequently low or non-existent. We can explain the ascendancy of the divination involving setbacks and guilt in part because it invoked the direct experiences of most Spartans. It was based on things they could see. And Sparta was, as I have tried to show elsewhere, a society in which the visual was privileged. ${ }^{49}$ Later, king Agesilaos can be seen exploiting the divinatory force of the visual. In organising at Ephesos the spectacle of a city as 'a workshop of war', Agesilaos had brought together various forms of military practice: 'you could see the gymnasia full of men exercising, the hippodrome full of horsemen riding etc'

\footnotetext{
49 Powell (1989). The commander of the Ten Thousand in Asia, Cheirisophos, who is, thanks to Xenophon, one of the most closely described of all Spartans, is shown appealing repeatedly to direct perception: 'You can see', 'Look ... and see', '... as you see', '... you can see' (Xen., Anab. III, 4, 39).
} 


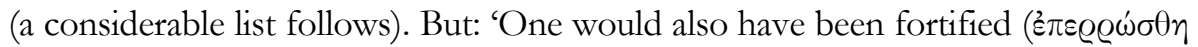
$\ldots \dot{\alpha} v)$ to see first Agesilaos then the other soldiers wearing garlands... which they offered up to the goddess Artemis [patroness of Ephesos]. For wherever men revere the gods, train for war and practise to obey the authorities, there it can be expected that everything will radiate optimism.' (Xen., Ages. I, 26f.; Hell. III, 4, 16-18 is almost identical). That optimism, concerned with war and in part derived from religion, is, as Xenophon makes utterly clear, derived from what is seen.

There was, however, another (related) reason for Spartans in $414 / 3$ to put special weight on the divination about their own guilt and suffering in the earlier, Archidamian, war. In the circumstances of $414 / 3$, such reflections conduced to hope. Thucydides uses them to explain why the Spartans judged the moment a good one to renew war. This time ( ó$_{\varepsilon} \delta \dot{\eta}$, VII, 18, 3) things were different; this time it was the Athenians who were indulging in the illicit action which had once brought suffering upon Spartans. Thucydides, with emphasis and some repetition, cites (like Xenophon later) secular and religious considerations together. It seemed to Spartans a good moment to attack because Athens would be distracted by two wars, against themselves and against Sicilians. Spartans drew strength

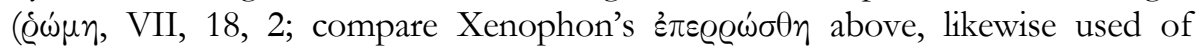
military optimism) from the thought that Athens would thus be easier to conquer. In listing Sparta's reasons for re-opening war now, Thucydides explicitly privileges these two: $\mu \alpha^{\prime} \lambda_{\iota} \sigma \tau \alpha \delta \delta^{\varepsilon} . . .$, 'But what most fortified the Spartans were...' - the secular thought about Athens' double war and the religious one about the Athenians having been the first to break the peace-treaty and thus being likely to suffer for their demerits as Sparta once had for hers. Again, this optimism of $414 / 3$ instantiates a marked tendency among Spartans, their especially acute form of the Greek sense of kairos, of military opportunity..$^{50}$ A time when an enemy was weak was a time for Sparta, with its limited manpower, to strike. What the present passage of Thucydides adds to our knowledge of this pattern is that, for Spartans, enemy weakness might take the form not only of military exposure, as identified by secular reasoning, but also of moral exposure, of setbacks to be anticipated for religious reasons. And now we may see a resemblance between Spartan calculations, secular and religious, in 431 and in 414/3. In 431 Athens was militarily exposed, a large proportion of its hoplites far away at the siege of Poteidaia. ${ }^{51}$ But she was religiously exposed as well, with Apollo asserting his hostility. Both considerations, the secular and the divinatory, might help to hurry the Spartans to action, and might even have helped to deflect them from timeconsuming arbitration, in 431. Like the siege of Poteidaia, Apollo's alignment

50 Powell (1980). On Spartan attention to timing, Richer (2007), p. 246, well adduces the report of Diogenes Laertius (II, 1) that in the the sixth century Sparta sought to acquire sundials from Anaximander.

51 Thuc., I, 61f.; I, 64, 2f., with Powell (1980), p. 99. 
with Sparta might not last for long, and should be exploited while it was available. The divination which prevailed in 414/3, like that of 431, played to an established strategic mentality.

For Athens, after 413, we hear little about any influence of divination on affairs of state. The débâcle in Sicily had led to mass anger against (in Thucydides' phrase) 'oracle-specialists and manteis and whoever else by using divination had made them hope to capture Sicily' (VIII, 1, 1). Of all Thucydides' briefer references to the power of prophecy this is perhaps the most tantalising in its lack of detail. His phrase does, however, suggest something of the scale of the optimistic prophecy, which corresponds with detail he gives us about the extent and influence of pessimistic prophecy among the expeditionary force during its last days. ${ }^{52}$ Perhaps part of the post-Sicilian reaction was the law alluded to in Plato's Laches (199a) against manteis' overruling generals on campaign. Plutarch's Nikias reflects understandable attempts, in the interest of later diviners, to show that the decision to stay at Syracuse after the lunar eclipse did not involve any inherent weakness in the art of divination..$^{33}$ The discredit into which soothsaying had fallen among many Athenians may have lasted long after the Sicilian expedition. ${ }^{54}$ For Spartans we know of no such reason for religion to decline in influence. There is, rather, a remarkable continuity in its prominence. And much of the detail which survives on this subject concerns the most conspicuous Spartan individual of the period, Lysandros, the victor of Aigospotamoi.

\section{Lysandros, and the accession of Agesilaos}

Sparta's custom, of presenting its own history in a series of highly moralising anecdotes concerning individuals and (especially) their deaths, made it probable that Lysandros would be acutely aware of the need not to be assimilated to one man above all: the regent Pausanias. The two commanders had much in common, as no doubt Lysandros' Spartan contemporaries would point out (cf. Athen., 543b-c). Each had led to triumphant conclusion a war against a most dangerous enemy. Each then acquired a position of personal eminence and power outside Sparta which made men look to him for leadership rather than to Sparta's (other) authorities. Each was in consequence exposed to strong resistance within Sparta, whether from jealousy or from concern for Sparta's levelling constitution. The danger that Lysandros would follow Pausanias' path to a bad end was very likely

52 POWELL (1979), p. 25-31.

53 Nik., 23 with POWELL (1979), p. $27 \mathrm{f}$.

${ }^{54}$ FLOWER (2008), p. 139 on the significant disappearance from Aristophanic comedy of references to chresmologoi after the failure of the Sicilian expedition. For renewed Athenian regard for military divination after the Peloponnesian War, see the epigraphic evidence concerning Sthorys of Thasos, granted Athenian citizenship in recognition of prophecy given before the Battle of Knidos (394): IG II², 17 with (e.g.) JACQUEMIN (2000), p. 101. 
obvious to Lysandros himself. Much that he did after his conquest of Athens is explicable as an attempt to resist the assimilation. Such resistance was all the more necessary because the logic of his position continued to press him in a similar direction to that taken by Pausanias - and not least when, having proved to the world and to himself his high competence, he found himself, as Pausanias had been after his victory, sidelined within his own city.

In contrast to Pausanias (as portrayed in Spartan story), Lysandros did not indulge in the luxury which his situation made possible. We hear that enormous sums of cash which came into his hands after Aigospotamoi were sent to Sparta with an exact tally (Plut., Lys., 16); other moneys seem to have been sent to shrines, as we shall see, for the bribing of others. The conqueror of the Athenian empire was to die, according to report, without any great personal wealth (Theopomp. ap. Athen. 543b-c; Plut., Lys., 30). Nor could he be accused, as Pausanias had been, of treasonable dealings with the enemy. He seems to have championed a policy of extreme ferocity towards defeated Athens. ${ }^{55}$ Towards Persia, the power with which Pausanias had reportedly had private dealings, Lysandros would again take a position of outright aggression after the death of the Persian prince, Kyros, with whom he had been allied in accordance with official Spartan policy. Like Pausanias, Lysandros advertised victory by placing a monument at Delphoi, the notice board of the Greek world. And like his predecessor he could not resist doing so in a way which advertised himself. Lysandros had his statue as centrepiece of the extravagant 'Navarchs' Monument', which recalled to visitors at Delphoi the victory of Aigospotamoi. ${ }^{56}$ But that monument involved a conspicuous difference from the physical record left at Delphoi by Pausanias the regent. The latter had offended his peers at Sparta by using a monument at Delphoi to name himself as the conqueror of the Medes (Thuc., I, 132, 1-3). Lysandros' monument signalled his own uniqueness: Pausanias the periegete tells that Lysandros was shown being crowned by divinity, by Poseidon (X, 9, 7). But the monument also had statues of some thirty other naval commanders. Did Lysandros hope by creating this small crowd to avoid the resentment aroused by the regent's singular claim? In addition there were statues of other intimate colleagues: Lysandros' steersman and - mentioned first among these colleagues by our source - his mantis. The latter's name, according to Pausanias the periegete, was Agias, and he was the grandson of the Elean seer Tisamenos (III, 11, 5f.). The diviner who acted for Lysandros at Aigospotamoi was thus the direct descendant of the man who had acted as mantis for regent Pausanias at the battle of Plataia.

At this point it may be forgivable to undertake a speculative reconstruction. Surviving accounts of the engagement at Aigospotamoi tell of five successive sorties by the Athenian fleet, each time challenging the Spartan fleet to battle,

\footnotetext{
55 POWELl (2006).

${ }^{56}$ Bommelaer (1981), no. 15; CARTLEdGe (1987), p. 35f., 82-5.
} 
each time - the challenge refused - sailing back to its base on the northern shore of the Hellespont. After the fifth refusal, Athenians were relaxed to the point of dispersing from their ships and became easy prey for Lysandros' unexpected descent.

With hindsight this whole procedure might look like brilliant planning on the Spartans' part. But should we assume that Lysandros had initially anticipated the particular form of opportunity which the Athenian dispersal offered? 57 Perhaps he did; he might have remembered the story about Kleomenes' victorious tactic against the Argives, who themselves made the mistake of assuming that Spartan patterns of military behaviour would continue unaltered (Hdt., VI, 77f.). But we should also recall the role ascribed by Herodotos to the soothsayer Tisamenos at Plataia. The latter announced that each of the sacrifices which he performed resulted in omens requiring that Spartan forces stay put, refrain from attack; this they reportedly did, in spite of extraordinary pressure, until at last the omens turned positive (IX, 36, 61f.). His opposite number, the Greek seer in the Persian camp, is recorded as advising likewise, and as being amply paid for his work: IX, 37f. To be master of timing was, as we have seen, the mantis particular role. Xenophon would later record the enormous reward - ten talents - given by Prince Kyros to a Greek seer who had correctly forecast the timing of enemy movements (Anab. I, 7, 18). Such prophecy affecting tactics would be especially valued no doubt by Spartans, given their own high sense of strategic kairos. One may surely speculate that Agias' role at Aigospotamoi was similar, perhaps even in conscious imitation of his ancestor; that it was a series of delays inspired, in part, by himself that presented Lysandros with an unpredicted opportunity in the form of Athenian relaxation. And there is some late evidence which tallies interestingly with such a hypothesis. The writer Pausanias in the second century AD visited Sparta and recorded that a bronze statue of this Agias had been erected there. He states, 'They say that this Agias, by his performance as mantis for Lysandros, captured the Athenian fleet by Aigospotamoi... Agias was the son of Agelochos the son of 'Tisamenos, the Elean who... etc.' (III, 11, 5f.) We note the (to us) extraordinary fact that Agias, rather than Lysandros, can be described as the person who defeated the Athenians. This is even stronger than the phrasing Herodotos used of Agias' grandfather: the latter 'by acting as mantis was jointly

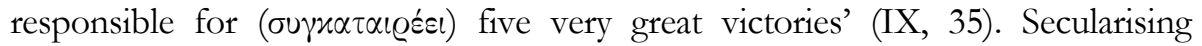
critics may wonder whether, from diverse secular motives, Lysandros and others exaggerated the role of Agias. Lysandros might have done so to avoid comparison with the egoism of Pausanias the regent, but also, and more subtly, to suggest that, just as he had a special relation with the god of sea and earthquake, he also

\footnotetext{
57 That Lysandros sent his fastest ships on each occasion to follow the withdrawing enemy fleet, to observe the Athenians' subsequent disembarkation and then to report, could have been done, as Xenophon indeed suggests, in a defensive spirit - to ensure that Sparta's naval crews only disembarked once it was safe, once Athens' own crews had done so (Hell. II, 1, 24).
} 
was (through Agias) the recipient of particularly helpful signals from divinity. Sparta would surely be wise to reappoint a man with such privileged connections. His opponents in turn might retrospectively have boosted the role of Agias in a contrary spirit, to dilute Lysandros' personal achievement. Indeed, diviners associated with Spartan military success may have served generally as devaluers of the achievement of generals, of kings, in accordance with the spirit of levelling among the homoioi. Was that perhaps part of the reason for the lasting acclaim attached to the Elean Tisamenos, whose hereditary association with divination could challenge that inherited by kings? In any case, the prominence of Agias in the monument at Delphoi, and in the words of Pausanias the periegete, suggests that - unlike the Athenians - the Spartans ended the Peloponnesian War with a fortified sense of the value of military soothsaying, and of the worth of hereditary specialists in that sphere.

Both during that war and after Sparta's victory, there continued savage internal politics involving royalty and eventually Lysandros. Before the battle of Mantineia (418), Spartans had turned on king Agis (Thuc., V, 63). He was blamed for military setbacks and for not profiting from what they saw as an unprecedentedly good opportunity ( $\pi \alpha \varrho \alpha \sigma \chi o ̀ v ~ \varkappa \alpha \lambda \tilde{\omega} \varsigma \omega \varsigma$ oủ $\left.\pi \omega \pi \varrho o ́ \tau \varepsilon \varrho o v^{58}\right)$ to crush Argos (again). It was proposed to demolish his house (as had been done in the case of the exiled Leotykhidas; Hdt., VI, 72) and to fine him 100,000 drakhmai. Thucydides indicates that the state came close to executing these punishments, which in effect would have meant disgrace and permanent exile, but settled instead for severely restricting Agis' right to take military initiatives. A body of 10 commissars was attached to him, to control decisions to lead out the Spartan army; this should recall the body of officials which, according to Xenophon, witnessed the inspection of omens over which a king presided at similar strategic moments. A king from the other royal house, the Agiad Pausanias who succeeded his father Pleistoanax, had profound differences of foreign policy with Lysandros; these are most obvious in policy towards Athens (Plut., Lys., 21 for 'the kings' as jealous and fearful of Lysandros' power in this connection). King Pausanias would effectively spare the city in 403 and allow its exiled democrats to return to power. Lysandros, almost certainly, had more drastic plans but was, late in the day, overruled by royal authority. ${ }^{59}$ Pausanias was subsequently put on trial for his actions at Athens; although acquitted, he was obviously the target of powerful elements within Sparta's ruling circles. Lysandros himself suffered what was very likely a painful and partisan humiliation when, at the same period, his trusted colleague in the victorious naval campaigns against Athens, Thorax, was

58 We thus have another statement in Spartan style, combining a broad assertion about the past with claim about a single exception. Indeed, in this short chapter of Thucydides two further statements allege that behaviour of the Spartans was by their standards unusual or unprecedented: $\mathrm{V}, 63,2,4$.

${ }^{59}$ For references to this and to the rest of the present paragraph, see POWELL (2006). 
put to death at Sparta on a charge of possessing silver; Lysandros' party is recorded as having previously argued for coinage to be used at Sparta (Plut., Lys., 17). How royalty stood on that question is not recorded. But when, in a later year (395), Lysandros was killed in warfare abroad, Pausanias - who had been campaigning nearby - was brought to trial again, this time no doubt amid resentment at his not having prevented Lysandros' death. He was exiled, permanently.

Lysandros' engagement against royalty was remembered as having extended widely. And divination was recorded as among his chief instruments. At the death of king Agis, in 400, the succession was disputed. Agis himself had seemingly cast doubt on the legitimacy of the person who claimed to be his son, Leotykhidas. The king is recorded (by Plutarch, Ages., 3; Lys., 22) as having waited suspiciously late, until the end of his life, to acknowledge the boy as his heir. ${ }^{60}$

A rival candidate for the throne was Agesilaos, younger half-brother of the late Agis. Xenophon, elsewhere the frank eulogist of Agesilaos, records in his Hellenica that Agesilaos had the prominent backing of Lysandros. The latter's motive was very likely the hope that Agesilaos would prove helpful, if not subservient, to his own interest; Lysandros had been, reportedly (Plut., Ages., 2; Lys., 22), the lover of Agesilaos in the latter's youth, and such relationships were supposed at Sparta to involve moral dominance, the formation of the younger male's character by the older. Xenophon's account of the confrontation between the two factions in this matter, so important for the standing of his revered Agesilaos, is hardly trustworthy in what it asserts. Agesilaos or his supporters would very likely pass to Xenophon a version contrived to validate the future king's cause. ${ }^{61}$ But in another sense Xenophon's account may be even more revealing, because more general in its implication: it showed how Spartans thought they should resolve such matters.

On this occasion too, secular argument is accompanied by divination. Each side argued from parental attitudes to Leotykhidas' paternity, but also from the text of a supposed oracle. Xenophon and Plutarch, while diverging in other respects, concur in this. Agesilaos in Xenophon's account suggests that an earthquake drove Leotykhidas' true father into the open. Plutarch writes that, according to Agesilaos, the earthquake had driven Agis from his wife's bed for a period, within which time Leotykhidas was conceived (Ages., 3 with Cartledge 1987, 113). Xenophon tells of a 'very eminent oracle-specialist, Diopeithes' who spoke in support of Leotykhidas and adduced what he claimed to be an oracle of Apollo, one which warned Sparta against a lame kingship. Plutarch helpfully emphasises that Agesilaos was lame (Ages., 2); Xenophon tactfully leaves the

60 This episode is the subject of a masterly narrative and analysis in CARTLEDGE (1987), p. $110-15$.

${ }^{61}$ In Xenophon's account, the young Leotykhidas gives away his case by implicitly accepting the claim that Agis refused to acknowledge him, and by arguing instead that the word of his mother should be believed in that she 'knew much better than he [Agis] did'; Hell. III, 3, 2. 
matter implicit. Plutarch diverges from Xenophon also by supplying a text, in four hexameters, of the alleged oracle. Both writers represent Diopeithes as arguing against allowing a lame man to become king, and Lysandros as successfully arguing that in reality the oracle excluded Leotykhidas because, if one of the dyarchs was not of the royal, Heraclid, descent, the kingship itself would be lame - metaphorically.

Who was this Diopeithes, whose intervention was not only tolerated but taken so seriously in an obviously capital affair? We note that the legitimacy of his 'Apolline' oracle is not challenged, even though nothing is said to indicate that Spartans had a precise idea about its origin. In neither of our sources is a patronymic or ethnic given for Diopeithes. Xenophon, as we have seen, stresses his eminence as oracle-specialist; Plutarch does likewise, perhaps with irony. Scholars have rightly suggested that the person in question was identical with the Diopeithes mentioned in three different Athenian contexts by the comedian Aristophanes (Knights, 1085; Wasps, 380; Birds, 988). The first of these comic passages refers to Apollo as 'riddling' about Diopeithes' hand, the second passage refers perhaps to wild bravado, to a 'soul filled with Diopeithes'. In the Birds, a character who is in dialogue with a chresmologos speaks about oracular language and uses the phrase 'not if he is Lampon or the great Diopeithes'. Since Lampon had been the foremost Athenian mantis of his day, his name twice given by Thucydides at the head of a list of those swearing on the Athenian side to an agreement with Sparta $(V, 19,2 ; 24,1)$, 'the great Diopeithes' is either in his company because he too was very well known, or - by comic inversion - because he was ridiculously outclassed in importance by Lampon. The former explanation is better; all three comic passages are highly allusive, that is, lacking in detail about Diopeithes; the audience each time is assumed to know well who he is. The latest of the Aristophanic passages, that from the Birds, is of 414 . We cannot be sure that Diopeithes was still alive in that year. But if he was, 414 would be close enough to the time of Agesilaos' accession (400) to encourage speculation that the Diopeithes involved in each case was one and the same. There are several possible reasons for Athenian Diopeithes to have come to ply his craft at Sparta. Spartans at the period might have provided a more respectful audience, with more grounds than the Athenians for heeding religious prophecy in political affairs. Spartan material support for divination could now draw on the wealth diverted from the Athenian empire. And Lysandros, whose faction Diopeithes sought to obstruct, had in 404-3 been drastically more anti-Athenian than fellow Spartans who opposed him. He had not only presided over the destruction of the Athenian fleet and empire; he had also apparently sought the destruction of Athens itself. In seeking to block Lysandros' scheme to install Agesilaos as king, Diopeithes might well consider himself to be on a patriotic mission. That the Athenian Xenophon did not think it necessary to describe the diviner here as an Athenian might even have been due to his notoriety. The case may be similar to 
that of Tisamenos: a foreigner, reputed for his specialism, allowed to regulate Spartan royalty to a degree, because of the faith which Spartans put in his craft.

In explaining why Lysandros prevailed over the specialist soothsayer in the interpretation of the oracle, we may add, to considerations of Lysandros' secular (albeit contested) authority, a further religious motive. At the time when Thucydides was writing, Spartans - as we have seen - were still telling of an earlier divinely-inspired earthquake, sent to punish a Spartan offence. Xenophon's account of Agesilaos' repartee against Leotykhidas has him referring to another earthquake, one which unmasked the adulteration (probably, it was understood, by an Athenian, Alkibiades) of a Heraklid's royal bed. Synchronism was so often a key to why an event was seen as ominous. A coincidence in time between earthquake and such signicant adultery might well be represented as numinous. And according to the wording we have in Xenophon, that is how Agesilaos did represent it. The latter reportedly informed Leotykhidas, 'But Poseidon gave evidence against your lying account by driving your father out of the bedroom and into the open with an earthquake'. Agesilaos then went on, according to Xenophon, to say that You were born in the tenth month from the moment when he took flight and appeared no more in the bedroom' (Hell. III, 3, 2). Now, this is a slightly unexpected way to make a point which, to our secular thinking, would have been more simply and effectively made by saying, 'And you were born in the tenth month from then.' The point about the lover's thorough absence from Timaia's bedroom might even, for secular thinking, weaken Agesilaos' case rhetorically, in that it ruled out subsequent days on which the interloper could have fathered the boy. But his reported words would make good sense if Agesilaos was implicitly claiming not only that relevant adultery had not happened after the earthquake, but also that it had not happened before: that Poseidon, in other words, had reacted with perfect timing, immediately the offence took place. Once more it may seem that, for Spartans, appeal to a publicly-witnessed event made for more persuasive divination than did an oracular text unsupported by such.

\section{The conspiracy of Kinadon - or of Agesilaos?}

Within a year of Agesilaos' contested succession, the Spartan authorities announced the discovery of a conspiracy against the Spartiate class and its rule over the southern Peloponnese. Here too, as we shall shortly see, divination has an important role in the narrative. The conspirators were alleged to be (or to include) men of inferior grades, led by one Kinadon who was apparently, although a non-Spartiate, of standing to be entrusted with sensitive official business. Aristotle mentions Kinadon briefly, as a person of manly qualities excluded from the highest status and driven thereby to mount an attack against the Spartiates. In the same sentence, he presents the case of Lysandros as an 
instance of a narrow regime provoking sedition: 'when individuals of stature and second to none in their personal qualities are dishonoured by men of higher status, as Lysandros was by the kings' (Pol., 1306b). We shall return shortly to the question of Lysandros' own sedition. But an awareness of the extreme tensions within the ruling group of Spartiates could have made plausible a conspiracy at this time, in accordance with the principle observed by Aristotle, that the helots, lie in wait, as it were, for disasters' affecting the Spartans. Aristotle's comments about Kinadon confirm the importance (which is not to say the truth) of the narrative we have concerning him. That narrative comes, however, primarily from Xenophon (Hell. III, 3, 4-11). He (to repeat) was the contemporary and eulogist of king Agesilaos, and Agesilaos would be himself among the prime targets of any plot, indeed plotters might have been inspired by the presumption that this controversial and inexperienced dyarch would initially be weak. How should we interpret Xenophon's narrative of the conspiracy?

Paul Cartledge writes of Xenophon's account: 'Above all ... it illuminates as if by a whole battery of arc-lamps the form and character of the Spartan class struggle' $(1987,165)$. He is right, and we should note that it is general phenomena which he describes as revealed in strong - and artificial - light. Not every detail of Xenophon's account here can be relied on. That account had to be persuasive in so far as it dealt with things publicly familiar, such as the approximate (and overwhelming) ratio of helots to Spartiates - or the availability of torture in public before execution for those who challenged Spartiate ascendancy. ${ }^{62}$ Points which Xenophon's narrative mentions incidentally, without stress, are among the likeliest to be true. But when he narrates the central and sensational 'facts', those far from publicly testable, in short what would have been to contemporary Spartans 'newsworthy', we should be far more sceptical. Such were Kinadon's supposed guilt, his confession, the identity of his few, intimate associates, and of his intended allies, the hosts of those belonging to various underclasses who would supposedly be glad 'to eat the Spartiates, even without cooking them first' (Hell. III, 3, 6). The Spartans had, according to Thucydides' account of an episode from the 420s, put to death very large numbers - some 2000 - of helots who were not only innocent but who had claims to be of exceptional loyalty and helpfulness to the Spartiates. The purpose of that slaughter had been to head off potential revolt of the helot class more generally, and the Spartans' procedure of identifying and assembling the 2000 victims had involved some of the most cynical and well-organised lying in history (Thuc., IV, 80, 3f.). Should we really be sure that the Spartiates could not, for raisons d'etat, have made victims now of a

\footnotetext{
62 Contrast How and Wells (on Hdt., IX, 37, ad loc.) who state, concerning the sufferings Sparta might impose on the condemned seer Hegesistratos, 'the Greeks did not use torture except for slaves'. The reality of Kinadon's conspiracy is doubted by Lazenby, for whom it 'may... have been little more than a smokescreen laid by the Spartan authorities to obscure the circumstances which had led to Agesilaos' coming to the throne' $(1997,438)$.
} 
few innocent - and impressive - men? We shall shortly consider details of another alleged plot involving as leader no less a figure than Lysandros, one elaborately planned but never put into action. This other plot, belonging within a few years (or less) of Kinadon's alleged conspiracy, was itself reportedly discovered by Agesilaos. This plot too had as target the kings. Plutarch commented that Lysandros had constructed, for his conspiracy, a scenario recalling a theatrical plot, that of a tragedy (Lys., 25). It may be that we should treat the bright lights constituted by Xenophon's narrative of Kinadon as akin to theatrical spotlights, revealing here too an elaborate mise-en-scène.

Significantly, for the purpose of the present study, the idea that divination involved in each plot was expected by the plotters to be credible is not emphasised or treated as a 'newsworthy' claim; instead, it is a given. Spartans were expected to trust their diviners. And the role of these prophets in the narrative of Kinadon's conspiracy is itself important. The existence of a plot was first suspected, according to Xenophon, because a mantis reported that thrice in succession the entrails resulting from Agesilaos' official sacrifices were bad: on the third occasion so bad as to cause him to exclaim, 'Agesilaos, what this suggests to me is that we are already surrounded by enemies' (Hell. III, 3, 4). Within five days of this inspired report (a chronology by which Xenophon or his source surely intended to signal that the mantis' warning was well-founded), the first informer brought to the ephors detail of a plot led by Kinadon. Xenophon then narrates how Kinadon was successfully deceived by the authorities, and induced to leave Sparta so that he could be arrested discreetly. Detail is given on how the deception was achieved, with Kinadon being presented with a situation which would seem to him quite normal. It is as if someone telling the tale was proud of Spartiate efficiency in the matter. We recall Xenophon's approving reports concerning Agesilaos in other contexts - that the king outclassed his Persian enemy Tissaphernes in the matter of deceit as thoroughly as an adult outclasses a child (Ages. 1, 17), and that he boosted the morale of his own men by lying to them about the outcome of the battle of Knidos. Here, in the case of Kinadon's conspiracy, Xenophon may well have thought he was following Agesilaos' own version of events; he claims to know, as we have just seen, the words of the soothsayer in conversation with the king. We may, that is, in reading of the conspiracy of Kinadon, be following a narrative supplied ultimately by a proudly accomplished liar at the head of the Spartan state.

How would we, and the Spartans in general, know - other than from soothsaying - that there had been a conspiracy at all? Apart from the account of the initial, timely informer, the pièce à conviction, as presented by Xenophon, is Kinadon's own confession. That Kinadon should confess truthfully and name his associates is presented by Xenophon - implicitly - as natural, predictable and requiring no special comment (III, 3, 10f.). Now Kinadon, as someone the Spartans had already trusted to arrest others (III, 3, 8f.), would have a good idea of what the Spartans would do to himself as a self-convicted insurrectionist, bent 
on attacking the Spartiate class with weapons. It seems that Xenophon has suppressed another predictable element of the affair: torture. ${ }^{63}$ Compare his delicate silences elsewhere on matters embarrassing, or at least distasteful, to Sparta: the fate of the thousands of Athenian sailors sentenced to death (and killed) after Aigospotamoi, ${ }^{64}$ the details of Sparta's defeat at Leuktra, ${ }^{65}$ or indeed the ultimate fate of Kinadon himself, whom Xenophon describes as being led around Sparta with his fellow-plotters, hands bound and neck in a 'dog-collar',

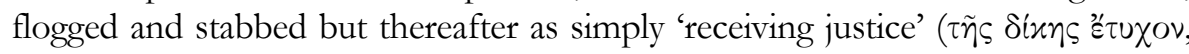
III, 3, 11). And if torture was involved, Kinadon might of course say anything that he thought the Spartiates wanted to hear. Or he might say nothing, his 'confession' provided for him. Spartiates themselves might doubt the reality of confessions in such a case. Was that, perhaps, why the official story was so emphatic about the soothsayer's dire warning at the start: did it need divination for most Spartans to be sure that there had been a plot at all?

Another soothsayer was prominently involved in the story. Unlike the seer who gave the initial warning, this second prophet is named: Xenophon refers to him with the expression 'the mantis Tisamenos and the other most important

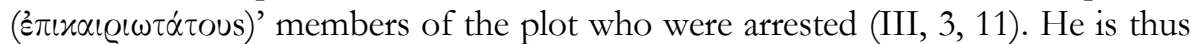
prominent in the tale ${ }^{66}-$ as well he might be. For this Tisamenos bears the most distinguished name in the history of soothsaying at Sparta. He was almost certainly a relative of the revered Tisamenos who had advised the Spartans during and after the Persian Wars. We have seen that Agias, recorded as the grandson of the great Tisamenos, was remembered as the mantis who successfully guided Lysandros at Aigospotamoi, and was enduringly honoured alongside his general on Lysandros' monument at Delphoi. The tale of Kinadon's conspiracy seems to present another of the mantic family, in all likelihood a Spartiate, as conspiring against the regime. Again, we cannot be sure that this younger Tisamenos had any part in any plot. But for the Spartan authorities to have been willing at least to ruin the reputation of so eminently-connected a prophet, and probably to put him to death with Kinadon and the others, should suggest a pre-existing rift within ruling circles.

63 The very brief account of the conspiracy given by Polyainos (II, 14, 1; drawing on Ephoros? - DAVID [1979], p. 244) states explicitly that Kinadon was tortured and that his fellowconspirators were put to death.

64 POWELL (2006), p. 293.

65 Grote (vol. 10, ch. 78, p. 165) describes Xenophon's account of the battle as 'obscure, partial, and imprinted with that chagrin which the event occasioned to him'.

${ }^{66}$ David suggests that communication between fellow-seers may have been the route by which Agesilaos' mantis came to know of a plot involving the seer Tisamenos (1979, p. 254). Jehne argues attractively that Xenophon used his narrative of the sacrifices, by which the gods revealed the plot to Agesilaos, to suggest that the latter's succession to the kingship had indeed been legitimate and as such was divinely approved (1995, p. 170-172). 
Xenophon introduces the story of Kinadon's plot immediately after ending the account of Agesilaos' accession, an accession which had been contested on divinatory grounds. The link with Agesilaos is emphasised: 'Agesilaos had been king for less than a year when, while he was sacrificing in the regular and

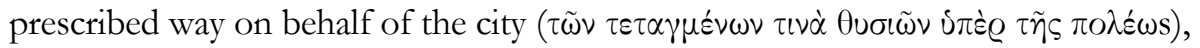
the mantis stated that the gods were indicating a plot of the most serious kind' (III, 3, 4). We observe Xenophon's emphasis on the proper, official nature of the sacrifice. Such a sacrifice was very likely to be understood as having reliable, official witnesses, as in the military sacrifices which Xenophon records elsewhere in connection with Agesilaos. We are not to think that Agesilaos had suborned a mantis for his personal ends, or that the mantis had spoken privately. Subversive manteia, as Xenophon will shortly make clear, belonged to Kinadon's faction. We should surely consider the possibility that the whole episode was a coup mounted by Agesilaos to kill some, and to intimidate many more, of those who continued to resent, if not to resist, his irregular installation as king. Those many Spartiates who feared or disapproved of Lysandros would be likely to resent the latter's choice of king - until such time as Agesilaos distanced himself definitively from his eminent patron. And since the accession of Agesilaos had involved ignoring the prima facie meaning of a supposedly Apolline prophecy, it would be likely enough that opponents of the new king would be supported by one or more of Sparta's soothsayers. The younger Tisamenos, if indeed of the Iamid line, would be aware that his family owed its eminent position at Sparta to the endorsement given by Delphic Apollo to Tisamenos the elder. The role of this Tisamenos in the story of the conspiracy has been somewhat neglected in otherwise good modern accounts. ${ }^{67}$ Yet he has more of a claim to prominence and influence at Sparta even than the trusted Inferior Kinadon. It is conceivable that, if Agesilaos did create or inflate the 'conspiracy of Kinadon', to eliminate Tisamenos was one of his chief aims. Plutarch records that later, after the catastrophic defeat at Leuktra in 371, Spartans censured Agesilaos for his improper accession and the disregard of the oracle about lameness, and blamed him for the general collapse of Spartan power (Ages., 30, cf. 34; Comp. Ages. and Pomp., 1). Here, it seems, is another case of an oracle brought to a high level of influence by dramatically visible events. But local opposition to Agesilaos had recurred over the intervening decades, and may indeed have been continuous. Killing those internal opponents - even Spartiate women ${ }^{68}$ - whom he thought dangerous is apparent in the king's later career, albeit from sources other than Xenophon. So is carefully-staged grand deceit in a religious setting. In passing off the débâcle at Knidos as a victory,

\footnotetext{
${ }^{67}$ However, GROTE (vol. 9, ch. 73, p. 319) names him among 'malcontents formidable both from energy and position'.

${ }^{68}$ For Xenopeitheia and her sister Khryse, Ath., 609b with CarTLedge (1987), p. 150, 375 and Powell (1999), p. $409 f$.
} 
Agesilaos is recorded as having sacrificed cattle in celebration and as having 'distributed the sacrificed animals widely' (Xen., Hell. IV, 3, 14). He would know that this benign fraud would be revealed as such before long; he evidently could rely on his fellow countrymen to approve his action. In contrast, if any deception involved killing trustworthy members of the Spartiate community, Agesilaos and his intimates might need to maintain the secret for ever.

\section{Lysandros: a plot against the hereditary dyarchy?}

A final episode for the present study involves elaborate prophetic machinations ascribed to Lysandros. His purpose was supposedly to consolidate his position at Sparta by replacing the hereditary dyarchy with an elected ruler, chosen on merit: he himself was to be that person. Analysing the matter we may perceive manipulation upon manipulation. But rather than dismiss our information as too unreliable to deserve much attention, we may once again study one of its chief presuppositions: that in deciding matters of their own high politics, Spartans depended profoundly on divination from non-Spartan sources. Surviving narrative of Lysandros' supposed plot is found chiefly in Diodorus (XIV, 13) and Plutarch (Lys., 24-6). ${ }^{69}$ Since Diodorus normally follows Ephoros for this period, and Plutarch (ibid., 25, 30) twice names Ephoros as his own source in this connection, it is virtually certain that the narrative goes back to the Fourth Century. Aristotle also refers to the matter, albeit briefly and guardedly: 'as some say that Lysandros tried to abolish the kingship' (Pol., 1301b, cf. 1306b). Plutarch (Lys., 30) represents elements of Lysandros' plot as having been discovered by Agesilaos while searching Lysandros' house after the latter's death in 395. There could hardly be a clearer warning than this for the modern - or ancient - source-critic. Agesilaos had clashed repeatedly with his former lover and promoter; the two men had a clear conflict of interests over who should have the main influence over Greek allies of Sparta in Asia Minor and elsewhere. ${ }^{70}$ Agesilaos might well wish to reduce the influence of Lysandros' domestic partisans even after his death; following that event, they evidently played a powerful role in the exiling of king Pausanias. And, of course, if even the single element was true, that Lysandros had entertained a scheme against the traditional dyarchy, Agesilaos as king had reason to present the affair in the most prejudicial light; we have already seen details of his attachment to salutary untruth.

Post mortem revelations of indefensible conduct by a contested Spartan leader were, as we have also seen, something of a narrative genre at Sparta. Such tales contrast significantly with the secrecy, or paucity of information, which - as Thucydides remarks $(\mathrm{V}, 68,2)$ - characterised Sparta's political arrangements as

69 The best modern discussion is that of CARTLEDGE (1987), p. 94-96. Also valuable are BOMMELAER (1981), p. 223-225; HAMILTON (1979), p. 88f., 92-96.

${ }^{70}$ CartLedge (1987), p. 152 for references and discussion. 
viewed by other Greeks. Sparta's lively concern to determine what potential enemies knew of the city obviously went to extremes: usually they had better know little or nothing, but sometimes they were presented with a tempting feast of detail. Plutarch's instinct is good when (Lys., 25) he repeatedly likens the plot to a contrivance of the theatre. If he made a mistake, it was to assume that the mise-en-scène was of Lysandros' own conception, rather than possibly the work of an enemy. According to Plutarch (Lys., 30), Agesilaos' first thought was to inform his fellow citizens, to show them what sort of man Lysandros had secretly been, but the king then decided against publication. The story evidently was not tested at the time by any sort of formal process to which defenders of Lysandros' memory might have had access. Informal and delayed diffusion of the story may of course have aided the cause of defamation. The motive given by Plutarch for Agesilaos' restraint was itself in keeping with the king's chosen image: he followed the advice of an ephor, that the story would not be beneficial to Sparta. He might also prefer not to be seen disseminating personally a tale which other Spartans would readily perceive as all-too-likely to profit himself, if not to be his own invention. ${ }^{71}$ At Sparta, a state resembling modern governments in its techniques of news-management, the king might well prefer the story to be leaked.

The tale of Lysandros' plot is, like the story of regent Pausanias' plot in Thucydides, long and detailed by the standards of our sources. Plutarch's version has a good anecdotal start, suggestive of a leisurely original: 'There lived in Pontus a poor woman who claimed to be pregnant by Apollo...' (Lys., 26). We must here, for brevity, be selective of detail, though that of course has its risks. Agesilaos claimed to have found, while searching Lysandros' house for other reasons, a speech written for him by one Kleon of Halikarnassos (otherwise unknown to us) advocating the principle of replacing Sparta's dyarchs with a ruler chosen on merit (Lys., 26, 30). Plutarch reports that Lysandros had learned the speech by heart, in the hope of convincing Spartans thereby. One asks immediately how the discovery of a written speech could have been accompanied by proper information that Lysandros had worked hard to master it. Further detail in the same context, as to Lysandros' thinking in deciding not to use the speech after all, again suggests construction beyond the evidence. Grote saw the difficulty in believing that a successful Spartan politician such as Lysandros could ever have imagined that his countrymen, famous for their proud rejection of elaborate rhetoric, could have been led to subvert their supposedly ancient constitution by a long speech. He sensibly suggests that any such speech from Kleon had been composed on the orator's own initiative as speculative flattery, from hope that Lysandros would reward it handsomely. ${ }^{72}$ Far more likely to impress Spartans was appeal to

${ }^{71}$ Possibly this may be why Xenophon himself, the king's eulogist, does not mention the affair, though $c f$. Hell. III, 4, 7 with CARTLEDGE (1987), p. 94.

${ }^{72}$ Vol. 9, p. 303 f. 
Delphic divination; and it is this which forms the main element of the alleged plot.

Lysandros, it is said, had hoped to procure from corrupt Delphic officials a prophecy stating that 'It would be better and more advantageous for the Spartans to choose their kings from among the best citizens'. To explain why this oracle had previously been unknown, it was to be claimed that Delphoi had long possessed a secret store of oracles, which could be revealed only by a son of Apollo. A young man, the son of the poor woman from Pontus, was to be presented as that person; he, with suitable staging and help from the complaisant Delphians, would dramatically reveal the oracle which so obviously pointed to Lysandros. The young man did duly come to Delphoi, but another of the key conspirators took fright and disappeared. Plutarch, ironically sustaining his theatrical imagery, writes that Lysandros 'failed to carry out his dramatic production ( $\delta \varrho \alpha \mu \alpha \tau o s$ ), through lack of daring on the part of one of the actors

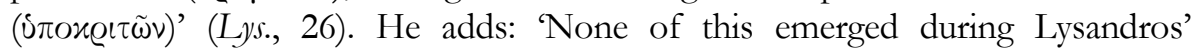
lifetime, but only after his death'. Plutarch allows his own disapproval of Lysandros to show at times, as when describing the 'uncountable slaughter of democrats' carried out by and for the Spartan leader (Lys., 19), or his deceptive use of feigned and ostentatious conduct and of sworn undertaking in order to bring about one such massacre; Plutarch here too uses the metaphor of 'staged'

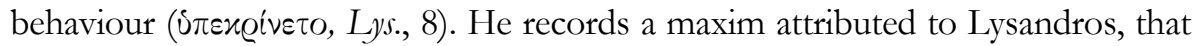
one should deceive children with knuckle-bones and adults with religious oaths, and states that he was untypical of Sparta in 'treating the gods as enemies' (ibid.). As one who himself became a priest of Delphoi, Plutarch's distaste at the planned corruption - that is, devaluation - of the shrine can be imagined. Significantly, he does not doubt the general story; it evidently fitted well with other recorded aspects of Lysandros' career.

To be plausible - and we recall that the story of Lysandros' plot was taken seriously, if not firmly believed, by Aristotle - a dramatic account which is clearly based on private information must cohere with noteworthy information which is public and deemed reliable. Persuasive elements of Lysandros' history which may already have been in the public domain, before the tale of the plot was launched, concerned his relations with the three leading shrines of the Greek world. Lysandros is recorded as having excused an absence from Sparta by claiming business which required his going to Zeus Ammon, in Libya. We are told, in some detail, that the authorities of Ammon thereafter complained to Sparta that Lysandros had tried to corrupt the shrine, a charge which was not upheld (Diod. Sic., XIV, 13). If we suspect that Agesilaos contrived most of the tale of a plot against the hereditary dyarchy, we should of course ask whether this story concerning Ammon was concocted by the same source. It is possible; but the events concerning Ammon - the departure thither of Lysandros and the arrival at Sparta of noteworthy figures from the shrine - were such that many at Sparta would be likely to know of their reality - or otherwise - during Lysandros' life- 
time. Lying on this score would have been perilous. Even more obviously public was Lysandros' intense interest in Delphoi, which he had adorned by the conspicuous and hugely expensive memorial to his victory over the Athenians. Plutarch (Lys., 18) would later pass on a report from one Anaxandridas of Delphoi that Lysandros had left a personal deposit of slightly less than two talents at the shrine; if anything of this had been known at the time, it would also have added colour to stories of his having intended to bribe the Delphic authorities. As to the report, evidently from Ephoros (Plut., Lys., 25, cf. Diod. Sic., $\mathrm{XIV}, 13)$, that Lysandros had also attempted to suborn officials at the oracular shrine of Dodone, we have no indication whether it was current in Lysandros' lifetime.

An element fundamental both to this alleged plot, and to the controversy over Agesilaos' succession, is well put by Cartledge: 'As that legitimacy [of the Spartan kings] was grounded ultimately in the divine sanction won from Apollo at Delphi, oracular means were required to undermine it' $(1987,95)$. We have seen, in connection with the restoration of king Pleistoanax, that the idea of the kings' having been installed, with religious acts, at the very foundation of the Spartan state was plausible at Sparta in the 420s. The 'divinely-honoured kings' ( $\theta \varepsilon о \tau \iota \mu \dot{\eta} \tau$ ous $\beta \alpha \sigma \iota \lambda \tilde{\eta} \alpha s)$ were to have pride of place in decision-making, according to Delphic advice on the establishment of the Spartan constitution as commemorated in verses ascribed to a poet of the archaic era, Tyrtaios (Plut., Lyk., 6). The kings are apparently presented in the 'Great' Rhetra as $\alpha \varrho \chi \alpha \gamma \varepsilon$ '́ $\alpha$ s, 'founderleaders' (Plut., ibid.), which prose text could be presented by Plutarch as derived from Delphoi by Lykourgos (that is, long after the foundation of Sparta). ${ }^{73} \mathrm{We}$ have seen evidence of repeated, sometimes violent rejection of individual Spartan kings through the fifth century; and in the early fourth came the exiling of king Pausanias. Given the strength of resistance to particular kings, one might well imagine that the whole principle of hereditary kingship needed some very powerful defence in order to withstand pressure for its abolition. That defence very likely was religious belief, and faith in the extreme antiquity of the institution. This latter faith might itself have a religious element: the idea that the kingship could not have had the endaimonia or entykhia to last so long without sustained divine support. If Lysandros' plot was genuine, or if indeed it was faked by Agesilaos, it evidently reflected a grave problem for opponents of the principle of hereditary dyarchy. If Delphoi alone could undo what Delphoi itself had once sanctioned, the traditional close relationship of the kings with Delphoi, and in particular their guardianship of Delphic oracles concerning Sparta, gave the dyarchs a block. Even if Delphoi were to turn against the dyarchs it had long supported, unlikely in itself, the kings might suppress any prophecy which challenged their own interest. And since many Spartans in the case of Pleistoanax had supposed the Delphic oracle corruptible, a revolutionary utterance from the

${ }^{73}$ See, however, vAN WEES (1999), p. 23. 
shrine might itself be subject to incredulity - unless specially impressive circumstances attended it. The story of the plot reflects an understanding that some such sensational development was required, whence the idea that a son of Apollo might work the oracle in a haze of glory.

\section{Conclusion: divination and the insecure dyarchy}

The account of the religious plot mounted by Lysandros, so unsatisfactory to the source-critic, so unappealing to the rationalist historian, turns out to have a solid virtue: it proves that, in the fourth century, the idea of abolishing the hereditary dyarchy was in the air - certainly outside Sparta and almost certainly within it. The apparently nebulous tale from Antiquity calls attention to two modern errors of perspective, both structural. As historians, we have overestimated the solidity of the dyarchy, and thus of Sparta's constitution more generally, for two reasons. The first reason is that we have followed too closely the gaze of our principal sources. Herodotos writes unforgettably of the only king who came to a spectacularly good end: Leonidas. Thucydides dilates on king Arkhidamos, and Xenophon wrote at length explicitly, and perhaps at even greater length implicitly, about Agesilaos. Leonidas casts a positive aura on the kingship, while the latter two kings present for us an image of solidity. Arkhidamos was king for over forty years, and a long war is named after him; Agesilaos reigned for almost exactly forty years, and he is rightly taken as symbolizing Sparta's critical, long, period of decline. If we considered as often the full list of royal rulers in our chosen period, including those who are not for so long the focus of our sources, a drastically different picture might appear. To take first the Agiad house: ${ }^{74}$

- Kleomenes (c. 520-490): died violently at Sparta, while in bonds.

- Leonidas (490-480): died in battle after a reign of some ten years.

- Pleistarkhos (480-458): for long a minor, with, as regent -

- Pausanias (480-c. 470): effectively put to death by Spartan authorities.

- Pleistoanax (458-408, with interruption): exiled for almost half of his reign, living in sanctuary for fear of Spartan violence. Pressed by serious accusations after his restoration.

- Pausanias (408-395): twice put on trial at Sparta, exiled permanently on the second such occasion: spent some time living in sanctuary from fear of the Spartans (Plut., Lys., 30).

Then the Eurypontid house:

74 The dates used here are, for the most part, those of Cartledge in his Spartan king-lists: (1987), p. 101. 
- Damaratos (515?-491): driven into permanent exile, where initially he was hunted by the Spartan authorities.

- Leotykhidas (491-469): condemned by a Spartan court to be handed over to Aigina; later, after Xerxes' invasion, driven into permanent exile, his house demolished by the Spartan authorities.

- Arkhidamos (469-427).

- Agis (427-400): threatened with ruinous fine and destruction of his house - in other words with permanent exile.

- Agesilaos (400-360).

It appears that, over the period 500-395, most (seven out of eleven) royal rulers of Sparta were either killed, enduringly exiled or threatened with exile.

Now, the later the viewpoint of a Spartan within that period, the more likely it would have seemed to him - from ordinary induction - that current dyarchs would also come to a bad end.

But here we reach the second modern error of perspective. We ourselves are likely to be seduced by a mentality which besets historians of every level: hindsight. Just as (for example) every historian knows that a great syllabus is opening with Agrippa's victory at Actium, and is likely to think (unless he or she struggles against the idea, consistently) that Romans of the time held a corresponding view about the Principate then beginning, ${ }^{75}$ so we are surely tempted to assume that Agesilaos on his accession felt he had a long future as king. We risk missing, or exploring too little, the insecurity he might feel as he acceded after unusual contest to a post which would predictably come under fierce attack. By attending to the long list of Sparta's troubled kings, we better understand both the account of the conspiracy of Kinadon and that of Lysandros' anti-regal plot. Whether true, much exaggerated, or untrue, each account reflects a realistic view that the very institution of the dyarchy had little left to commend it, according to contemporary Spartan opinion - save for religious considerations. But those religious considerations were themselves far from insignificant, whence their prominence in the sources.

It seems, then, that within the period of Spartan history for which our information is most extensive, from the reign of Kleomenes to that of Agesilaos, religion formed a commanding element in Spartan decision-making, on matters which contemporaries knew to be of the highest importance. By attending to this use of divination we also come to perceive the enduring insecurity of Sparta's most prominent authorities, the kings. This fragility in the kingship may seem to be at odds with a feature of Sparta's society prominently and well studied in recent times: her extraordinary royal funerals. Famously, Herodotos 'makes strange' these funerals to the extent of comparing them to royal obsequies of

\footnotetext{
${ }^{75}$ For examples of such modern hindsight, POWELL (2008), p. 21 f.
} 
barbarian Asia, a territory for Greeks symbolic of slavish subordination to autocratic rulers. Spartan society - Spartiates, Perioikoi and helots - mobilised on a grand scale for noisy and spectacular rituals, at which the newly-dead king was cried up as the best king yet (Hdt., VI, 58-60). Xenophon writes, of the burial of Agis II, that its 'grandeur seemed to exceed what a mere mortal man could claim' (Hell. III, 3, 1), and that deceased kings were regarded as heroes rather than as dead mortals (Lak. Pol., 15, 9). The functions of a funeral are varied and subtle. Cartledge brings out this complexity with exactitude and caution. Parker also writes attractively, Nothing brings out the realities of hierarchy and power as well as a funeral. ${ }^{76}$ But the forms of a royalist ceremony, gaudy or sombre, may seduce. Is it perhaps the case that one element in these assertive funerals amounted in effect to 'Argument weak: shout!? Spartans, those experts in the application of timing, would know that a funeral, in many cultures a time for the mentality of De mortuis nil nisi bonum, was the right moment to venture an extreme compliment towards royalty in a polis where royal power was forcefully contested. Agis, with his more-than-mortal funeral honours, was someone who in his lifetime had been the object of widespread rage among his fellow citizens and of serious attempts to evict him from Sparta. Perhaps our closest and most telling analogue to the royal funerals is the elaborate ceremony to re-install Pleistoanax as king in the early 420s, with its choruses and sacrifices supposedly identical to those which had accompanied the original installation of Sparta's kingship, centuries before, at the very founding of the polis. This too was Pleistoanax's moment of strength, in a career characterised by weakness: restored, for religious reasons, after some two decades in humiliating and dangerous exile, he faced domestic enemies who would be powerful enough in future to impose, indirectly, the direction of his foreign policy. He used his moment, as others perhaps used the royal funerals, to assert - defensively - the antiquity of his office and its fundamental importance to the Spartan state. Religion had been his means of self-protection against fellow-Spartans while in exile, at the sanctuary of Lykaion; religious ceremony was likewise his medium of self-defence on returning to his city.

As to the importance of prophecy in general among Spartans, does there remain any reason why the convergent testimony of Herodotos, Thucydides, Xenophon and later Greek writers should be accorded unusually little critical attention, or respect? In the light of Sparta's talent for official lying and mythmaking, one might wonder whether the image of a uniquely pious Sparta was itself a consciously false instrument of Spartan foreign policy; whether opponents were expected to be demoralised by the thought that, in Herodotos' words, the Spartans 'put considerations of the gods before considerations of men' (V, 63; cf.

76 On the meanings of these royal funerals see PARKER (1989), p. 152f.; MiLLENDER (2002), p. 2-11, and above all CARTLEDGE (1987), p. 104f., 332-42. 
IX, 7). But such an idea would require the further assumption that Spartan authorities, while possibly cynical themselves, supposed other Greeks, at least, to believe that religiously correct behaviour did lead to divine support. Moreover, much of our information on Spartan trust in divination concerns scandal and division within Sparta, matters hardly contrived to impose on outsiders an idea of Spartan superiority. Internal Spartan arguments about whether Pleistoanax had corrupted the Delphic oracle, and thereby brought on Sparta repeated divine punishment, are likely to have had a very different effect if circulated abroad. Similarly with other cases of apparent obedience to divination. Parker is quite right to ask, 'Whose interests could it serve in 419, for instance, to summon the perioikoi for a secret expedition, march out "no one knew whither", disband the army on the borders of Argos on the pretence that the crossing-sacrifices were adverse, and re-assemble a force for a second expedition against Argos later in the year?' (1989, 158, citing Thuc., V, 54f.) The modern sceptic might perhaps have recourse to the idea that, while Spartans in general were privately disbelievers of divination, as individuals they tended to judge that they had better appear not to be, for fear of offending a majority opinion at Sparta which they incorrectly believed to be more pious - and that historians from other cities thus came to share in the mirage of Spartan religiosity. Such an idea could not be disproved, but a more economical hypothesis is available: that, in imputing to their own society a profound faith in divination, the Spartans were not abnormally unperceptive.

Anton POWELL

E-mail:powellanton@btopenworld.com

\section{Bibliography}

Berthiaume, G., 'Citoyens spécialistes à Sparte’, Mnemosyne 29 (1976), p. 360-364.

Bommelaer, J.-F., Lysandre de Sparte, Paris, 1981.

Cartledge, P., 'Seismicity and Spartan society,' LCM 1 (1976), p. 25-28.

Cartledge, P., Agesilaos and the crisis of Sparta, London, 1987.

DAvid, E., 'The conspiracy of Cinadon', Athenaeum 57 (1979), p. 239-259.

FLOWER, M.A., The seer in Ancient Greece, Berkeley, 2008.

Flower, M.A., 'The Iamidae: a mantic family and its public image', in B. DignAs and K. TRAMPEDACH (eds), Practitioners of the divine: Greek, priests and religious officials from Homer to Heliodorus, Cambridge (Mass.), 2008, p. 187-206.

Fontenrose, J., The Delphic oracle, Berkeley, 1978.

Grote, G., A history of Greece (12 vols), Everyman Edition, no date, London.

Hamilton, C.D., Sparta's bitter victories. Politics and diplomacy in the Corinthian war, Ithaca, 1979.

Hodkinson, S., 'Social order and the conflict of values in classical Sparta', Chiron 13 (1983), p. 239-281.

Hodkinson, S., Property and wealth in classical Sparta, Swansea and London, 2000. 
Holladay, A.J. and Goodman, M.D., 'Religious scruples in ancient warfare', CQ 36 (1986), p. 151-171.

Hornblower, S., A Commentary on Thucydides, vol. 1, Oxford, 1991.

Hornblower, S., 'The religious dimension to the Peloponnesian War, or, What Thucydides does not tell us', HSCP 94 (1992), p. 169-197.

Hornblower, S., 'Thucydides and the Athenian boule', in L. Mitchell and L. Rubinstein (eds.), Greek history and epigraphy: essays in honour of P.J.Rhodes, Swansea, 2009, p. 251-264.

How, W.W. and WeLls, J., A commentary on Herodotus (2 vols), Oxford, 1912.

JACQUemin, A., Guerre et religion dans le monde grec, 490-322 av. J.-C., Paris, 2000.

Jehne, M., 'Die Funktion der Berichts über die Kinadon-Verschwörung in Xenophons Hellenika', Hermes 123 (1995), p. 166-174.

Johnston, S.I., Ancient Greek divination, Malden, 2008.

Lazenby, J.F., 'The conspiracy of Kinadon reconsidered', Athenaeum 85 (1997), p. 437-447.

Mass-ObServation, Puzzled people, London, 1947.

Millender, E., 'Herodotus and Spartan despotism', in A. Powell and S. Hodkinson (eds.), Sparta: beyond the mirage, Swansea and London, 2002, p. 1-61.

Millender, E., 'The Spartan dyarchy: a comparative perspective' in S .HodKINSON (ed.), Sparta: comparative approaches, Swansea (forthcoming, 2009).

PARKE, H.W., A bistory of the Delphic oracle, Oxford, 1939.

PARKE, H.W., The oracles of Zeus, Oxford, 1967.

Parke, H.W. and Wormell, D.E.W., The Delphic oracle (2 vols), Oxford, 1956.

PARKer, R., Miasma. Pollution and purification in early Greek religion, Oxford, 1983.

Parker, R., 'Spartan religion', in A. Powell (ed.), Classical Sparta: techniques bebind her success, London, 1989, p. 142-172.

Popp, H., Die Einwirkung von Verzeichen, Opfern und Festen auf die Kriegführung der Griechen im 5. und 4. Jabrbundert v. Chr., diss. Erlangen, 1957.

Powell, A., 'The role of religion in Athenian foreign policy, 480-346BC', diss. London, 1973.

Powell, A., 'Religion and the Sicilian expedition', Historia 28 (1979), p. 15-31 [= 1979a].

Powell, A., 'Thucydides and divination', BICS 26 (1979), p. 45-50 [= 1979b].

Powell, A., 'Athens' difficulty, Sparta's opportunity', AC 49 (1980), p. 87-114.

Powell, A., 'Mendacity and Sparta's use of the visual', in id. (ed.) Classical Sparta: techniques bebind her success, London, 1989, p. 173-192.

Powell, A., 'Sixth-century Lakonian vase-painting: continuities and discontinuities with the "Lykourgan" ethos', in N. Fisher and H. van WeES (eds.), Archaic Greece, Swansea and London, 1998, p. 119-146.

Powell, A., 'Spartan women assertive in politics? Plutarch's Lives of Agis and Kleomenes' in S. HodkInSON and A. POwEll (eds.), Sparta: new perspectives, Swansea and London, 1999, p. 393-419.

Powell, A., Athens and Sparta, London, $2001^{2}$.

Powell, A., 'Why did Sparta not destroy Athens in 404, or in 403BC?' in S .Hodkinson and A. POwELl (eds.), Sparta and war, Swansea, 2006, p. 287-303.

POwELL, A., Virgil the partisan. A study in the re-integration of classics, Swansea, 2008.

PRITCHETT, W.K., The Greek state at war: part 3, religion, Berkeley, 1979. 
Richer, N., 'The religious system at Sparta' in D. Ogden (ed.), A companion to Greek religion, Oxford, 2007, p. 236-252.

Stephenson, F.R. and Fatoohi, L.J., 'The eclipses recorded by Thucydides', Historia 50 (2001), p. 245-253.

van WeEs, H., 'Tyrtaeus' Eunomia: nothing to do with the Great Rhetra', in S. HodKINSON and A. Powell (eds.), Sparta: new perspectives, Swansea and London, 1999, p. 1-41.

Zeilhofer, G., 'Sparta, Delphoi und die Amphiktyonen im 5. Jahrhundert vor Christus', diss. Erlangen, 1959 (non vidi). 